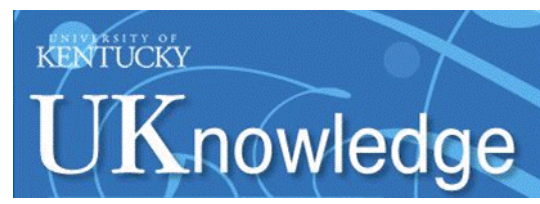

Kentucky Law Journal

2013

\title{
Justice Holmes's Bad Man and the Depleted Purposes of Punitive Damages
}

Jill Wieber Lens

Baylor University School of Law

Follow this and additional works at: https://uknowledge.uky.edu/klj

Part of the Judges Commons, and the Torts Commons

Right click to open a feedback form in a new tab to let us know how this document benefits you.

\section{Recommended Citation}

Lens, Jill Wieber (2013) "Justice Holmes's Bad Man and the Depleted Purposes of Punitive Damages," Kentucky Law Journal: Vol. 101: Iss. 4, Article 5.

Available at: https://uknowledge.uky.edu/klj/vol101/iss4/5

This Article is brought to you for free and open access by the Law Journals at UKnowledge. It has been accepted for inclusion in Kentucky Law Journal by an authorized editor of UKnowledge. For more information, please contact UKnowledge@lsv.uky.edu. 


\title{
Justice Holmes's Bad Man and the Depleted Purposes of Punitive Damages
}

\begin{abstract}
Jill Wieber Lens ${ }^{1}$
$\int \mathrm{s}$

ustice Holmes introduced his bad man as a tool to separate law and morality. The bad man is not affected by morality and sees a tort duty only as an obligation to pay damages. The bad man does not consider any chance of escaping liability, so he sees that obligation as mandatory. Applied hypothetically to punitive damages, the bad man would not appreciate the morality basis for imposing punitive damages or the moral condemnation and stigma that traditionally results from that imposition. Instead, he sees punitive damages as just another check that he will be required to write.

In Exxon Shipping Co. v. Baker, the Supreme Court made this hypothetical application a reality. Acting within its common law authority, the Court explained its ideal system for imposing punitive damages, citing Justice Holmes's bad man, and necessarily depleting the traditional common law punishment and deterrence purposes of punitive damages. No longer is that punishment purpose based in morality, and the deterrence purpose lacks any specific deterrence goal. The Court's depletion of these common law purposes weakens the policy behind punitive damages. But more importantly, the depletion undermines the damages' constitutionality, which depends on the damages' traditional common law purposes.
\end{abstract}

\footnotetext{
I Associate Professor of Law, Baylor University School of Law. J.D., University of Iowa College of Law; B.A., University of Wisconsin. The author thanks Todd Pettys and Luke Meier for their valuable comments on earlier drafts. The author also thanks Heidi Rasmussen, Baylor J.D. 2014, and Taylor Kilway, Baylor J.D. 2014, for their valuable research assistance. The author also thanks her then newborn daughter, Hannah Madison, who was sleeping on the author when she made her final edits and submitted this piece. Any mistakes are, of course, the author's.
} 


\section{INTRODUCTION}

In Exxon Shipping Co. v. Baker, ${ }^{2}$ the Supreme Court concluded that maritime law limited the punitive damage award imposed in the case to the amount of the compensatory damage award. Compared to the Court's various constitutional limitations on punitive damages, Exxon Shipping Co. seems harmless mostly because it was based on maritime law, which is federal common law. Just a few years before, the Court held that a punitive damage award could punish the defendant only for what he did to the plaintiff. ${ }^{3}$ Exxon Shipping Co., by comparison, was just a little boat case.

Do not be fooled, however, as Exxon Shipping Co. has far-reaching effects on the constitutionality of punitive damages. The basis of Exxon Shipping Co. is maritime law, which is federal common law that integrates tort common law on punitive damages. Thus, this case afforded the Court its first opportunity to address punitive damages from a tort law perspective and explain their punishment and deterrence purposes. These same common law purposes are what justify, constitutionally, the imposition of punitive damages. Change the purposes, change the constitutionality.

And the Court did indeed change the purposes; it depleted both the punishment and deterrence rationales. In describing the ideal system for imposing punitive damages, the Court cited Justice Holmes's famous bad man-explaining that "even Justice Holmes's 'bad man" must be able to look ahead and know the amount of punitive damages he will face. ${ }^{4}$ To fit this system and be consistent with Justice Holmes's bad man, the Court necessarily altered punitive damages' traditional punishment and deterrence purposes.

The Court's conception of punishment is detached from its traditional morality roots. Justice Holmes introduced his bad man in a theory aimed at separating law and morality. Applied to punitive damages, the effects are dramatic. Morality controls what conduct is punishable, and the award of these damages expresses the jury's moral condemnation, which stigmatizes the defendant. Without morality, all of these aspects of punitive damages are lost. The Court also divorces punitive damages from morality within its own definition of the damages and its choice of the $1: 1$ ratio in the case. More important than the loss of morality, however, is that the Court did not replace the substance of the punishment purpose. The Court describes punitive damages that may "punish," but we're not sure why or how.

With respect to the deterrence purpose, long before Exxon Shipping Co., the Court made clear that the damages' deterrence purpose was less constitutionally powerful than the punishment purpose. ${ }^{5}$ When given the

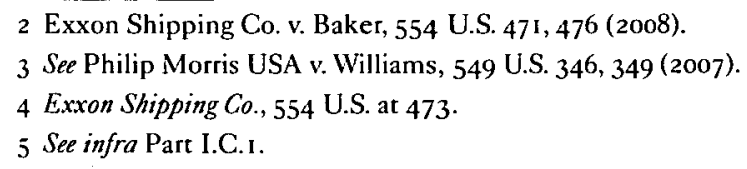


chance in Exxon Shipping Co. to more clearly define that purpose, the Court declined and left the purpose lacking. The citation to Justice Holmes's bad man, who assumes he will pay compensatory damages, rejects the inclusion of either optimal or complete deterrence within the damages' common law purpose. The Court also affirmed the imposition of punitive damages despite guaranteed liability, which is inconsistent with optimal deterrence. Ultimately, in Exxon Shipping Co., the Court describes the damages' deterrence purpose generically without any specific aim.

The Court has imposed numerous constitutional limitations on punitive damages. ${ }^{6}$ Ultimately though, punitive damages' common law punishment and deterrence purposes justify their constitutionality. In Exxon Shipping Co., a common law case, the Court undercuts that constitutionality by depleting the damages' common law purposes. Regarding punishment, damages divorced from morality cannot further state interests in punishing immoral actors, and imposing "punishment" without a basis for the imposition is not legitimate. As for deterrence, the Court identifies only a vague idea of deterrence, creating legitimacy problems, and continues to ignore the relevance of a defendant's chances of escaping liability, which affects the damages' ability to achieve any type of deterrence. Regardless of their constitutionality, if punitive damages seek to further punishment and deterrence based only upon arbitrary and unsubstantiated standards, there is no meaningful policy reason for their existence.

Part I of this article describes the origin of punitive damages and their constitutional relevance. Part II explores the appearance of Justice Holmes's bad man in the Exxon Shipping Co. decision and briefly describes the bad man theory. Part III argues that the Court's analysis in Exxon Shipping Co., including its citation of the bad man, leaves the punishment purpose of punitive damages with little substance and similarly hollows the deterrence purpose. Part IV explores the implications of the Court's described depleted common law purposes of punitive damages-namely, the likely unconstitutionality of punitive damages.

\section{The Punishment and Deterrence Purposes of Punitive Damages}

Punitive damages are civil damages exceeding the amount necessary to compensate a plaintiff. ${ }^{7}$ Tort law awards punitive damages to fulfill its interests in "punish[ing] wrongdoers and deter[ring] wrongful conduct[.]"8

6 See infra discussion Part I.C.

7 See Exxon Shipping Co., 554 U.S. at 49 I (explaining that punitive damages are damages "beyond the compensatory").

8 Restatement (Second) of Torts $\$$ gou(c) ( 1979); see also Exxon Shipping Co., 554 U.S. at 49I (explaining that the historical purposes of punitive damages were to "punish[] ... extraordinary wrongdoing" and to deter by setting an example); State Farm Mut. Auto. Ins. Co. v. Campbell, 538 U.S. 408,416 (2003) ("IP] unitive damages serve a broader function; they 
Courts created punitive damages to fulfill the distinct purposes of punishment and deterrence.

These same purposes are relevant to a constitutional challenge to a punitive damage award. The imposition of damages fulfills these traditional purposes and furthers state interests in punishing and deterring tortfeasors.

\section{A. Courts' Creation of Damages to Punish and Deter}

The idea of imposing damages to punish has ancient roots in Babylonian and Roman law and is also found in the Bible. ${ }^{9}$ As an example, Roman law included a concept of multiple damages, which blended punishment with compensation and was used to constrain wealthy elites. Without multiple damages, a wealthy man could "“amuse himself by striking those whom he met in the streets in the face, and then tendering them the legal amends, from a wallet which a slave carried after him for the purpose." 10

The specific doctrine of punitive damages originated in English common law. In a pair of 1763 cases, Wilkes $v$. Wood ${ }^{11}$ and Huckle $v$. Money, ${ }^{12}$ English courts awarded formal "exemplary" damages to "punish and deter the misuse of wealth and power...."13 Generally, exemplary damages were available in cases involving intentional aggravated conduct. ${ }^{14}$ Scholars disagree about the precise purpose for the imposition of punitive damages in England, whether it was to compensate the plaintiff or purely to punish and deter the defendant. ${ }^{15}$ Whatever the original purpose, the law did "evolve to the point at which it was clear that the object of punitive or exemplary damages was to punish and deter." 16

Soon after their birth in England, punitive damages were awarded in America. ${ }^{17}$ Like in England, punitive damages were imposed only in cases

are aimed at deterrence and retribution."); BMW of N. Am., Inc. v. Gore, 517 U.S. 559, 568 (1996) ("Punitive damages may properly be imposed to further a State's legitimate interests in punishing unlawful conduct and deterring its repetition.").

9 Michael Rustad \& Thomas Koenig, The Historical Continuity of Punitive Damages Awards: Reforming the Tort Reformers, 42 AM. U. L. Rev. 1 269, I 285-86 (1993).

10 Id. at 1286 (quoting Vindictive Damages, 4 Aм. L.J. 6 I, 75 (1852)).

I I Wilkes v. Wood, ( 763 ) 95 Eng. Rep. 766; 2 Wils. K.B. 203.

12 Huckle v. Money, (1763) 95 Eng. Rep. 768; 2 Wils. K.B. 205.

I3 Rustad \& Koenig, supra note 9, at 1289.

14 Id. at 1287 .

I5 I John J. Kircher \& Christine M. Wiseman, Punitive Damages: Law and Practice 4-6 (2d ed. 2012).

$16 \mathrm{Id}$. at 7 .

17 Rustad \& Koenig, supra note 9, at 1290 (noting that punitive damages first appeared in a reported case in 1784 ); see also Day v. Woodworth, 54 U.S. 363,37 I (1851) ("It is a wellestablished principle of the common law, that in ... actions on the case for torts, a jury may inflict what are called exemplary, punitive, or vindictive damages upon a defendant, having in view the enormity of his offence rather than the measure of compensation to the plaintiff."). 
involving willful and wanton indignities. ${ }^{18}$ And, like in England, the law has evolved to the point that the clear purposes of the damages-i.e., the very reasons that the damages exist-are punishment and deterrence. ${ }^{19}$

\section{B. The Distinct Punishment and Deterrence Purposes}

The punishment and deterrence purposes of punitive damages are "not always in harmony with each other." ${ }^{20}$ As each theory requires different measures and can lead to different damage awards, the total amount of punitive damages may vary according to whether the approach is based on punishment or deterrence. ${ }^{21}$

1. Punishment Briefly Explained.-Although courts have always made clear that punishment, or retribution, is a purpose of imposing punitive damages, ${ }^{22}$ they "do not usually explain what they mean by punishment...." ${ }^{23}$ What they appear to have in mind, however, is that a punitive damage award is the defendant's "just deserts" for his immoral conduct. ${ }^{24}$ The moral culpability of the defendant and his conduct justifies

18 See Rustad \& Koenig, supra note 9, at 1291.

19 Exxon Shipping Co. v. Baker, 554 U.S. 47 I, 492 (2008); see also id. at 49 I -92 (explaining that even if punitive damages once served as compensation for intangible injuries, those injuries are now covered by compensatory damages).

20 Dan B. Dobbs, Law of Remedies: Damages-Equity-Restitution § 3.11(14), at 354 (2d ed. 1993).

21 See id. $\S 3.11(15)$, at 355 ; see also id. \$ 3.1I(3), at 324 ("[Punitive awards based on deterrence] may be measured quite differently from awards that seek to administer punitive just deserts....").

22 See supra note 8 and accompanying text.

23 DoBss, supra note $20, \& 3$. I I(2), at 3 I 9 n.2.

24 Id.; see also Dan M. Kahan, What Do Alternative Sanctions Mean?, 63 U. ChI. L. Rev. 59 I, 601-02 (I996) ("'A retributivist punishes because, and only because, the offender deserves it."' (quoting Michael S. Moore, The Moral Worth of Retribution, in REsPonsIBILITY, ChaRACTER, and the Emotions: New Essays in Moral Psychology 179, 179 (Ferdinand Schoeman ed., 1987))). The punishment purpose of punitive damages can become more complicated depending on whether it is limited to a private law function or can serve a public law function. If limited to a private law function, the punishment is limited to vindicating "the dignity of an individual victim by allowing her to punish the defendant for committing a humiliating or insulting tort upon her." Thomas B. Colby, Clearing the Smoke from Philip Morris v. Williams: The Past, Present, and Future of Punitive Damages, I 8 Yale L.J. 392, 434 (2008). If able to serve a public law function, the punishment could vindicate society's interest in punishing the defendant for his wrongful conduct. See Dan Markel, Retributive Damages: A Theory of Punitive Damages as Intermediate Sanction, 94 CoRnell L. REV. 239, 246 (2009) (introducing a punitive damage measurement that would achieve the public's interest in retributivist justice, which is one measurement within the pluralistic approach Markel advocates). 
the punishment..$^{25}$ It similarly controls whether to inflict punishment. ${ }^{26}$ If morally culpable, the defendant should be "made to suffer in a way that appropriately corresponds to his wrong." 27

2. Deterrence Briefly Explained.-Courts have also always made clear that deterrence is a valid reason for imposing punitive damages. ${ }^{28}$ Like with punishment, courts do not explain what they have in mind when they mention the "deterrence" purpose. Generally, deterrence is focused on discouraging future tortious behavior, an idea independent of "just deserts." ${ }^{29}$ But multiple concepts exist within "deterrence," and these multiple concepts can call for different measurements of damages.

The first distinction to draw is between specific and general deterrence. "In simplest terms, 'specific deterrence' seeks to deter the defendant ... from repeating a wrongful act." ${ }^{30}$ Specific deterrence is thus focused on deterring a specific defendant from committing the same conduct again. General deterrence, on the other hand, seeks to "deter others who might otherwise engage in the same type of conduct at issue in the lawsuit." 31

25 See DobBs, supra note $20, \S 3.1 \mathrm{I}(2)$, at 318 ("The punishment rationale holds that it is just to impose suffering upon a defendant who has engaged in extreme wrongdoing."); Kahan, supra note 24 , at $601-02$.

26 Alan Howard Scheiner, Judicial Assessment of Punitive Damages, the Seventh Amendment, and the Politics of Jury Power, 9 I Colum. L. Rev. 142, I 73 (1991) ("Whether to inflict punishment is a purely moral judgment").

27 Dobss, supra note 20, $\$ 3 . \mathrm{II}(2)$, at $3 \mathrm{I} 8$; see also State Farm Mut. Auto. Ins. Co. v. Campbell, 538 U.S. 408,426 (2003) (describing a "major role" of punitive damages as condemning immoral conduct).

28 See supra note 8 and accompanying text. Although the Supreme Court has referred to the purposes of punitive damages separately, deterrence is sometimes thought of as a "purpose of punishment, rather than ... a parallel purpose, along with punishment itselff.]" Kemezy v. Peters, 79 F.3d 33, 34 (7th Cir. 1996); see also Wayne R. LaFave \& Austin W. ScotT, Jr., Criminal Law \$ I.5(a), at 24-25 (2d ed. I 986) (listing deterrence and retribution as separate theories of punishment). Regardless of word choice, the Court recognizes a distinction between punishment and deterrence, which is further demonstrated by the Court's use of the words punishment and retribution interchangeably. In the article, the author will refer to the two purposes as "punishment" and "deterrence" and assume the same distinction that the Court gives the two purposes.

29 DoBBs, supra note $20, \S 3.1 \mathrm{I}(2)$, at 318.

30 Sheila B. Scheuerman, Two Worlds Collide: How the Supreme Court's Recent Punitive Damages Decisions Affect Class Actions, 60 Baylor L. Rev. 880, 887 (2008); see also A. Mitchell Polinsky \& Steven Shavell, Punitive Damages: An Economic Analysis, i I I HARv. L. Rev. 869, 877 n. I3 (I998) ("IS/pecific deterrence ... is the effect that the imposition of a sanction on a party will have on that party's future behavior.").

3 I Scheuerman, supra note 30 , at 887 ; see also Polinsky \& Shavell, supra note 30 , at 877 (" $[G]$ eneral deterrence [is] the effect that the prospect of having to pay damages will have on the behavior of similarly situated parties in the future (not just on the behavior of the defendant at hand)."). 
One problem that general deterrence theories focus on is the possibility that a potential defendant will escape liability for her torts. ${ }^{32}$ This will happen if the injured plaintiff does not realize his injury, or even if he does, he is unable to realize who caused his injury. ${ }^{33}$ Or, even if the injury is detected, the tort claim/remedy may go unenforced. For example, the plaintiff may choose not to bring a lawsuit if his damages are minimal or if he has a distaste for the legal system. ${ }^{34}$ Whether the chance of escaping liability is based on under-detection or under-enforcement, as long as the chance exists, defendants may be undeterred.

To remedy these chances of under-detection and/or underenforcement, one theory of general deterrence-the optimal deterrence theory-includes a cost-internalization calculation of punitive damages. The calculation is:

[P] unitive damages should be set at a level such that the expected damages of defendants equal the harm they have caused, for then their damage payments will, in an average sense, equal the harm. This implies a simple formula for calculating punitive damages, according to which harm is multiplied by a factor reflecting the likelihood of escaping liability. ${ }^{35}$

As an example, suppose the defendant misrepresented its car to be "new," even though the car was actually worth $\$ 4000$ less than a new car. ${ }^{36}$ Suppose further that the probability of being held liable was only two in fourteen, so $1 / 7 .{ }^{37}$ The cost-internalization calculation dictates that the amount of harm, $\$ 4000$, is multiplied by the chance escaping liability, 7 , totaling $\$ 28,000 .^{38}$ This total $\$ 28,000$ award would be based on $\$ 4000$ in

32 F. Patrick Hubbard, Substantive Due Process Limits on Punitive Damages Awards: "Morals Without Technique"?, 6o FLA. L. REv. 349, $3^{81}$ (2008) ("Detection of wrongdoing is of limited deterrent value if that wrongdoing is not sanctioned. Therefore, plaintiffs must bring suit if punitive damages are to provide the deterrent sanction."). This same issue can occur within specific deterrence also-even if a defendant has already paid punitive damages once, he still may choose to risk the conduct again based on the chances of under-detection and under-enforcement. Specific methods to fix the problems of under-detection and underenforcement, however, are usually more associated with general deterrence ideas.

33 Polinsky \& Shavell, supra note 30 , at 888.

34 Id. Polinsky and Shavell also point to the possibility that a defendant may "escape liability" because an injured plaintiff may not file suit if "the likelihood of establishing causation is low." Id. If the plaintiff cannot establish causation, the defendant would not be liable (and thus no liability for the defendant to "escape"). See infra note 254 and accompanying text (discussing that "escaping liability" is not a risk when liability is not possible).

35 Polinsky \& Shavell, supra note 30 , at 954.

36 See id. at 901 (discussing the calculation of damages in BMW of N. Am., Inc. v. Gore, 517 U.S. 559,568 (1996)).

37 See id. at 902.

38 See id. 
compensatory damages and $\$ 24,000$ in punitive damages. ${ }^{39}$ Under this calculation, defendants will end up paying damages based on the total amount of harm that they have caused even though not all injured plaintiffs successfully sue. ${ }^{40}$ If liability is guaranteed, no multiplication is necessary and the defendant should pay only compensatory damages in an amount "equal to the harm the defendant has caused." 41

The proponents of optimal deterrence believe that any amount of damages over the cost-internalization calculation will result in overdeterrence, causing defendants to undertake excessive precautions. ${ }^{42}$ Defendants will then pass on the costs of these precautions to consumers. ${ }^{43}$ Or, even worse, defendants will choose to not engage in the activity even though it is socially desirable. ${ }^{44}$

The other main theory of general deterrence-complete deterrencediffers from optimal deterrence in that it uses a gain-elimination calculation. ${ }^{45}$ Instead of taking into account the total harm caused, the calculation "requires the court to divide the defendant's gain by the probability of liability." 46 "[T]he penalty should be at least as large as the minimum of the illicit gain expected by the offender." ${ }^{77}$ To illustrate the difference between the two calculations: "If the offender gains $\$ 100$ from committing an offensive act that imposes a $\$ 10$ loss on his victim, the cost

\section{See id.}

40 See id. at $889-90$.

$4 \mathrm{I} I d$. at 878 . One exception exists to the inappropriateness of punitive damages if liability is guaranteed-if the tortious conduct "produces no social gain, only harm." Id. at 909. The example Polinsky and Shavell give is if the defendant punches the plaintiff with the intent to cause harm. Id. This type of conduct should be deterred completely, and total damages in excess of the plaintiff's harm may be necessary to achieve complete deterrence. Id.

42 Id. at 879 .

43 Id. at 882 .

44 Id. at $882-83$ (pointing to defendants' cessation of vaccine production because of potential tort liability).

45 Optimal deterrence contemplates that the conduct may continue, but the defendant must pay for the total harm caused. Dan Markel, Hore Should Punitive Damages Work?, I 57 U. PA. L. Rev. 1383, 1391 n. 18 (2009). The goal of complete deterrence, on the other hand, is that "zero instances of the particular misconduct would occur." Id. Even the proponent of the complete deterrence theory, Professor Keith Hylton, advocates the optimal deterrence cost-internalization calculation if the defendant's conduct is economically desirable. See Keith N. Hylton, Punitive Damages and the Economic Theory of Penalties, 87 Geo. L.J. 42 I, 428-30 ( 1998). Professor Hylton believes, however, that most punitive damages cases involve noneconomically desirable conduct. See id. at 423, 439-44.

46 Hylton, supra note 45 , at 423 .

47 Brief Amicus Curiae of Professors Keith N. Hylton et al. in Support of Respondents at 19, Philip Morris USA v. Williams, 549 U.S. 346 (2007) (No. 05-1256), 2006 WL 2688793. 
internalization approach would require a penalty of $\$ 10$, while the gain elimination approach would require a minimum penalty of $\$ 100$." 48

Like cost-internalization, however, the gain-elimination calculation factors in the probability of escaping liability ${ }^{49}$ If the defendant's total expected gain is $\$ 100$ and he is likely to escape liability half of the time, his punitive damage award should total at least the gain doubled. ${ }^{50}$ This is the only way to ensure the defendant is stripped of all of his illicit gains. ${ }^{51}$ Unlike optimal deterrence, there is no problem if damages exceed the gain doubled; the point is to completely deter, so overdeterrence is not problematic. ${ }^{52}$ Also unlike optimal deterrence, the complete deterrence theory leaves open the possibility for a punitive award even when liability is certain. ${ }^{53}$

\section{The Constitutional Justification of Punitive Damages}

The same purposes that justified the creation of punitive damages also justify them constitutionally. The question of the constitutionality of a punitive damage award "begins with an identification of the state interests that a punitive award is designed to serve." ${ }^{54}$ Those state interests mirror the purposes that justify punitive damages' existence-punishment and deterrence. ${ }^{55}$

An award becomes unconstitutional if it is " grossly excessive' in relation to" the state's punishment and deterrence interests. ${ }^{56}$ Because the state interests mirror the damages' common law purposes, the "grossly excessive"

$48 \mathrm{Id}$. at 12 . Professor Hylton refers to the $\$ 100$ as a minimum penalty and acknowledges that a greater penalty would also be acceptable; he is not worried about overdeterrence if the conduct is socially undesirable. See Hylton, supra note 45 , at $43 \mathrm{I}$.

$49 \mathrm{See}$ Brief Amicus Curiae of Professors Keith N. Hylton et al. in Support of Respondents, supra note 47 , at 16 ("Increasing the penalty to ensure that the infrequently-caught offender is stripped of illicit gains . . . is equivalent (in economic deterrence terms) to taking into account the harms done to others by an offender when punishing that offender.").

5o Id.

5I See Hylton, supra note 45 , at 460.

52 Id. at $43 \mathrm{I}$ (explaining that overdeterrence is not a concern because "society has no interest in permitting the offensive activity to occur, at any level.").

53 See id. at 453-54 (evaluating the facts of Exxon Shipping $C o$. and concluding that a punitive damage award is appropriate if the activity is characterized as "incompetently" "piloting supertankers," even though liability is certain).

54 BMW of N. Am., Inc. v. Gore, 517 U.S. 559, 568 (1996).

55 Mark Geistfeld, Constitutional Tort Reform, 38 Loy. L.A. L. Rev. 1093, I I 3 (2005) (explaining that the legitimate State interests that justify the imposition of punitive damages are "the substantive objectives or purposes to be served by tort liability"); see also $B M W$, 517 U.S. at 568 ("Punitive damages may properly be imposed to further a State's legitimate interests in punishing unlawful conduct and deterring its repetition.").

$56 B M W, 517$ U.S. at 568 . 
standard is the same as asking whether the award "unreasonably exceed[s] the amount required for purposes of punishment and deterrence." ${ }^{77}$

To help resolve this constitutional inquiry, the Court created three guideposts, ${ }^{58}$ which supposedly "adopt the common-law objectives of punishment and deterrence." 59 A closer evaluation of the guideposts, however, shows that they rely more heavily on the damages' punishment purpose than the deterrence purpose, meaning that the punishment purpose is more powerful constitutionally ${ }^{60}$ This idea is further supported by the Court's later holdings, which appear to conclude that damage measurements based on deterrence are unconstitutional.

1. The Punishment Purpose's Constitutional Power:-In BMWv. Gore, the Court announced three guideposts to evaluate the constitutionality of a punitive damage award. ${ }^{61}$ Briefiy, they are: 1) the level of reprehensibility of the defendant's conduct, 2) the ratio of the punitive to compensatory damages, and 3 ) the criminal or civil sanctions for comparable conduct. ${ }^{62}$ In reality, courts use only the first two guideposts, ${ }^{63}$ both of which reflect the damages' punishment purpose, rather than deterrence purpose.

\footnotetext{
57 Geistfeld, supra note 55 at I I I3.

$5^{8} \mathrm{BMW}, 5 \mathrm{I} 7$ U.S. at $574-75$.

59 Geistfeld, supra note 55 at I I I3.

60 See Catherine M. Sharkey, Economic Analysis of Punitive Damages: Theory, Empirics, and Doctrine, in Research Handbook on the Economics of Torts (Jennifer H. Arlen ed.) (forthcoming Nov. 2013) [hereinafter Sharkey, Economic Analysis] (manuscript at 16), available at http://ssrn.com/abstract=1990336 ("[T] he Court . . has intimated that punishment is the predominant purpose [of punitive damages], with deterrence perhaps an incidental effect.").
}

6I $B M W, 5$ I 7 U.S. at 574

$62 I d$. at $574-75$.

63 See Andrew C.W. Lund, The Road from Nowhere? Punitive Damage Ratios After BMW v. Gore and State Farm Mutual Automobile Insurance Co. v. Campbell, 20 Touro L. Rev. 943, 954 (2005) ("[C]ourts rarely apply the third guidepost. . . [T]he Court itself has expressed concern over the propriety of applying the third guidepost."). The Court has not explained this guidepost or addressed its numerous problems. Unaddressed issues facing courts include identifying comparable conduct (and consequently which sanction to examine) and the impossibility of comparing criminal or regulatory sanctions with punitive damage awards. Hubbard, supra note 32 , at $372-73$.

It is difficult to analyze the third guidepost in punishment or deterrence terms because of the Court's cursory application of it. In $B M W$, the Court pointed out that the maximum civil penalty for comparable conduct in any state was $\$ 10,000$, an amount dwarfed by the imposed $\$ 2$ million punitive award. $B M W, 517$ U.S. at $583-84$. In State Farm, the Court chose not to "dwell long" on the guidepost because, again, a state civil sanction of $\$ 10,000$ was "dwarfed by the $\$$ I 45 million punitive damages award." State Farm Mut. Auto. Ins. Co. v. Campbell, 538 U.S. 408,428 (2003). The analysis, however, likely depends on legislative intent. See Harmelin v. Michigan, 501 U.S. 957, 989 (1991) (explaining that the weight of punishment, deterrence, or even rehabilitation in determining a criminal punishment is an "eminently legislative judgment"). If the legislature set the amount of a statutory sanction with a punishment purpose in mind, then comparable punitive damage awards fulfill the punishment purpose. If the legislature set the sanction higher to account for the risk of under-detection or under- 


\section{a. Reprehensibility: The More Immoral the Conduct, the Greater the Punishment}

The thought behind the level of reprehensibility guidepost is that the amount of punitive damages should vary according to the defendant's culpability. A defendant who acts maliciously deserves to pay a greater punitive award than a defendant who acts recklessly. ${ }^{64}$ In constitutional terms, the state's interest is greater when the defendant acts maliciously, thus allowing a higher punitive damage award.

The level of reprehensibility guidepost focuses almost exclusively on the state's interest in punishment. Malicious conduct is more morally culpable than reckless conduct, thus a defendant who commits malicious conduct deserves greater punishment than a defendant who commits reckless conduct.

Given its focus on the punishment purpose, it is not surprising that this guidepost does not implicate the deterrence purpose of punitive damages. "That a defendant's conduct can be described as reprehensible is in itself irrelevant." ${ }^{65}$ Deterrence concerns are implicated when there is a chance of under-detection or under-enforcement. Reprehensibility does not control these chances. And focusing on reprehensibility can distort the deterrence purposes of punitive damages by imposing punitive damages even though liability is certain ${ }^{66}$ or not imposing punitive damages when conduct is socially undesirable but not reprehensible. ${ }^{67}$

enforcement, then comparable punitive damages would also fulfill the deterrence purpose. See Polinsky \& Shavell, supra note 30 , at 927-28.

64 See $B M W, 517$ U.S. at 575-76 (explaining that some forms of tortious conduct are more blameworthy than others). The Court further explained the factors to be considered regarding reprehensibility of conduct in State Farm:

We have instructed courts to determine the reprehensibility of a defendant by
considering whether: the harm caused was physical as opposed to economic; the
tortious conduct evinced an indifference to or a reckless disregard of the health or
safety of others; the target of the conduct had financial vulnerability; the conduct
involved repeated actions or was an isolated incident; and the harm was the result
of intentional malice, trickery, or deceit, or mere accident.

538 U.S. at 4 19. Additionally, the Court has explained that a profit motivation makes conduct more reprehensible. Exxon Shipping Co. v. Baker, 554 U.S. 47 I, 494 (2008). These factors can sometimes conflict; a profit motive makes conduct more reprehensible, but causing economic harm is less reprehensible than causing physical harm.

65 Polinsky \& Shavell, supra note 30, at 906; see also Gary T. Schwartz, Deterrence and Punishment in the Common Law of Punitive Damages: A Comment, 56 S. CaL. L. Rev. I33, 14I ( 1982 ) ("The common law's criteria governing eligibility for punitive damages-'malice,' 'recklessness,' and 'conscious disregard' for victim's rights-likewise seem out of line with the standards one would expect from a deterrence oriented system."). But see Hylton, supra note 45 , at $455-56$ (arguing that reprehensibility can be relevant in determining whether the defendant undertook the conduct to pursue a gain at the victim's expense).

66 Polinsky \& Shavell, supra note 30 , at $905-06$.

67 Id. at $907-08$. 
Some think this guidepost does reflect the deterrence purpose because the Court mentioned in $B M W$ v. Gore that repeated conduct is more reprehensible. ${ }^{68}$ Under-detection and under-enforcement, however, are usually not problems associated with a recidivist defendant who has been detected and already sued in tort. Plus, the Court expressed that repeated conduct should be punished more harshly because it is more immoral, not because of the need for deterrence. ${ }^{69}$

This guidepost also potentially reflects the deterrence purpose since the Court mentioned that attempts to conceal an injury increase the level of reprehensibility. Attempts to conceal could lead to under-detection. ${ }^{70}$ But the level of reprehensibility does not control the chances of underdetection, which can be high even without attempts to conceal. ${ }^{71}$ And again, the Court seems to believe that attempts to conceal should be punished more harshly because they make the conduct more immoral, not because of the need for deterrence. ${ }^{72}$

\section{b. Ratio: The More Harm Caused, the Greater the Punishment}

This guidepost dictates that "[d]efendants who do more harm should generally be punished more, and compensatory awards are the best available measure of harm caused." ${ }^{\text {" In }}$ constitutional terms, the state's interest is greater when the defendant causes a greater amount of harm, thus allowing a higher punitive damage award..$^{74}$

$68 B M W, 5$ I 7 U.S. at 577 .

$69 \mathrm{Id}$. ("Our holdings that a recidivist may be punished more severely than a first offender recognize that repeated misconduct is more reprehensible than an individual instance of malfeasance.").

70 Polinsky \& Shavell, supra note 30 , at 908.

7 I Id. Defendant's attempts to conceal the plaintiff's injury may be relevant to show the plaintiff's failure to detect the injury, but not controlling. See id.

72 See Pac. Mut. Life Ins. Co. v. Haslip, 499 U.S. I, 51 (1991) (O'Connor, J., dissenting) ("[T]he defendant's awareness of any hazard which his conduct has caused or is likely to cause, and any concealment or 'cover-up' of that hazard . . . should all be relevant in determining this degree of reprehensibility." (quoting Green Oil Co. v. Hornsby, 539 So.2d 2 I8, 223 (Ala. I989))).

73 Theodore Eisenberg et al., Reconciling Experimental Incoherence with Real-World Coherence in Punitive Damages, 54 STAN. L. Rev. I239, I264 (2002). But see Jill Wieber Lens, Procedural Due Process and Predictable Punitive Damage Aqvards, 2012 BYU L. Rev. 1, 45-46 (2012) (arguing the ratio guidepost is logically flawed because compensatory damages do not provide an objective judgment of the extent of harm); Anthony J. Sebok, Punitive Damages: From Myth to Theory, 92 IowA L. Rev. 957, 988 (2007) ("[J]uries do not treat a dollar's worth of harm the same regardless of the character of the wrong. ... [P]eople believe that a dollar's worth of injury warrants different degrees of punishment based on the nature of the injuryproducing conduct.").

74 The Court has refused to define any set acceptable ratios, but it has mentioned that single-digit ratios are most likely to be constitutional. State Farm Mut. Auto. Ins. Co. v. Campbell, 538 U.S. $408,410(2003)$. 
Like the level of reprehensibility guidepost, this guidepost involves the state's interest in punishment. It focuses on proportionality: the amount of punitive damages must be proportional to the harm that the defendant caused to the plaintiff. The more harm caused, the more immoral the conduct. As the Supreme Court has explained in the criminal law context, "[p]roportionality is inherently a retributive concept, and perfect proportionality is the talionic law," 75 which means that the punishment should match the crime.

Given proportionality's relevance to retribution, its irrelevance to deterrence should not be surprising. In the Court's own words, "it becomes difficult even to speak intelligently of 'proportionality,' once deterrence ... [is] given significant weight." ${ }^{76}$ Again, deterrence's main focus is on under-detection or under-enforcement. ${ }^{77}$ Proportionality, on the other hand, focuses on whether the punishment fits the tort, which, according to this guidepost, is defined by the amount of harm the defendant caused.

Although proportionality is inherently a retributive concept, the Court's explanation of this guidepost includes some deterrence-like language. For example, the Court specifically noted that a greater disparity between the amount of compensatory and punitive damages may be permissible if the plaintiff's injury is hard to detect or the plaintiff's compensatory damages are minimal, ${ }^{78}$ factors that increase the chances of under-detection and under-enforcement. This language is consistent with both optimal deterrence and complete deterrence ideas because it acknowledges that an award should be higher if the chances of escaping liability are high. ${ }^{79}$

75 Harmelin v. Michigan, 50I U.S. 957, 989 ( I991). But see Catherine M. Sharkey, The Exxon Valdez Litigation Marathon: A Window on Punitive Damages, 7 U. St. Thomas L.J. 25 , 28-29 (2009) [hereinafter Sharkey, Litigation Marathon] ("The Court has never even tried to relate the ratio factor to any underlying justification for punitive damages .... With respect to the punishment goal, the absence of a correlation between the mens rea ... of the wrongdoer and [the] measure of the actual harm inflicted should surprise no one.").

76 Harmelin, 501 U.S. at 989 ; see also Hubbard, supra note 32 , at 384 ("[D]eterrence provides a basis for punishments that are ... not proportional to wrongdoing.... Consequently, a jury might impose a punitive damages award that is 'disproportionately' high in terms of retribution to deter wrongdoing that is hard to detect or committed by a wealthy defendants."); Hylton, supra note 45 , at 454-55 (explaining that the requirement of some relationship between compensatory and punitive damages makes no sense if gain elimination is the goal of punitive damages); Sebok, supra note 73, at 988 ( "[A]nchoring punitive damages on compensatory damages ... does not cohere well within a theory of efficient deterrence.").

77 See Sharkey, Litigation Marathon, supra note 75, at 29 ("[T]he relevant relationship between punitive and compensatory damages [based upon deterrence purposes] focuses on the likelihood of detection, not the relative size of the compensatory damages.").

78 BMW of N. Am., Inc. v. Gore, 517 U.S. 559,582 (1996).

79 See supra note 49 and accompanying text. 
It is more consistent with optimal deterrence than complete deterrence, though, as the ratio looks to the harm the defendant caused the plaintiff. ${ }^{80}$

Although the Court has noted the possibility of a higher ratio, it has not explained when it is appropriate. ${ }^{81}$ Instead, the Court's opinions "appear to eliminate or minimize this detection concern." ${ }^{22}$ State Farm involved a factual scenario in which the chances of under-detection and underenforcement were high because the type of people injured by the conduct were unlikely to discover their injuries and/or unlikely to file suit. ${ }^{83}$ Justice Kennedy, however, labeled the case as "neither close nor difficult." " $[\mathrm{H}]$ is opinion appear[ed] to ignore th[e deterrence] concern and to focus solely on retribution because it simply concluded that 'the argument that State Farm will be punished in only the rare case ... had little to do with the actual harm sustained' by the plaintiffs." 85 Thus, the Court did not utilize that higher ratio in State Farm, even though it described the chances of under-detection and under-enforcement, and the resulting need for deterrence, as high.

\section{The Deterrence Purpose's Lack of Constitutional Power-The minimal} relevance of deterrence to the guideposts automatically limits its power and relevance in constitutionally justifying the amount of an award. But the Court has not completely negated that relevance. Years before it created the guideposts, the Court clarified that deterrence alone could justifyconstitutionally-the imposition of punitive damages. ${ }^{86}$ Similarly, even in

80 See supra note 45 and accompanying text; see also Hylton, supra note 45 , at $454-55$ ("In some cases where gain elimination is probably the appropriate goal of punishment, the search for some reasonable relationship between the compensatory and punitive portions of the award is likely to lead the court to choose an inappropriately small award-that is, an award that fails to secure the socially desirable level of deterrence.").

81 See Polinsky \& Shavell, supra note 30, at 899 ("[C]ourts occasionally refer to considerations that bear on the probability that a defendant would have escaped liability. But they rarely explain in a direct and systematic way how this probability should be used to determine the proper level of damages for deterrence purposes.").

82 Hubbard, supra note 32 , at 381 .

$8_{3}$ The victims of State Farm's conduct were poor, uneducated about their rights, lacking an alternative, and thus vulnerable to deceit. State Farm Mut. Auto. Ins. Co. v. Campbell, 538 U.S. 408, 433 (2003) (Ginsburg, J., dissenting).

84 Id. at 409.

85 Hubbard, supra note 32, at 38 I (quoting State Farm, 538 U.S. at 427).

86 In Pacific Mutual Life Insurance. Co. v. Haslip, the Supreme Court affirmed the constitutionality of imposing punitive damages on a defendant liable only because of respondeat superior. 499 U.S. I, 15 (1991). Respondeat superior holds an employer liable merely because it employed an employee and that employee committed a tort within the scope of his employment. See id. at 6 . The employer is not at "fault" and the punishment purpose cannot justify the imposition of punitive damages. But the Court affirmed the imposition of punitive damages under these circumstances based on deterrence: "Imposing liability without independent fault deters fraud more than a less stringent rule." Id. at 14 . "Imposing exemplary damages on the corporation when its agent commits intentional fraud 
$B M W$, the Court implied that deterrence could justify some award, just not the one at issue in the case ${ }^{87}$ And in his concurrence, Justice Breyer explained that deterrence "could permit juries to calculate punitive damages by making a rough estimate of global harm, dividing that estimate by a similarly rough estimate of the number of successful lawsuits that would likely be brought." 88

However, Justice Breyer's deterrence-based calculation did not live to see the light of day. The Court first subtly rejected it in State Farm, refusing to consider the possibility of other successful lawsuits, labeling those lawsuits as irrelevant to the plaintiffs' harm. ${ }^{89}$ This limits the application of both the cost-internalization and gain-elimination calculations of punitive damages because both consider the chances of a defendant escaping liability. ${ }^{90}$

In Philip Morris USA $v$. Williams, the Court made clear that the potential success of other lawsuits against the defendant for the same conduct was constitutionally irrelevant. ${ }^{91}$ In Philip Morris, the punitive damage award arguably included amounts that punished the defendant for harming nonparties (other people with potential tort claims against the defendant). ${ }^{92}$ The Court specifically held that a punitive damage award could not constitutionally encompass damages for the defendant's conduct to nonparties, ${ }^{93}$ which would include considerations such as whether the defendant was likely to escape liability for harm to nonparties.

creates a strong incentive for vigilance ...." $I d$.

The imposition of punitive damages based on pure respondeat superior theory, a theory that imposes liability despite the lack of fault, was also before the Court in Exxon Shipping Co. v. Baker: 554 U.S. 471,484 (2008). The Ninth Circuit upheld the imposition of punitive damages based on this theory, following the rule in the Second Restatement allowing punitive damages if the employee committing the tort was a manager. Id; see also Restatement (SECOND) OF TORTS $\S$ gOg(c) ( I 977 ).

The eight Justices who participated in Exxon Shipping Co. split evenly on this issue, meaning the Ninth Circuit's opinion was affirmed. 554 U.S. at 484 . Speculation is that the four Justices who wanted to reverse, possibly on the basis that punitive liability is inappropriate, were Chief Justice Roberts and Justices Scalia, Kennedy and Thomas. See Doug Rendleman, Common Law Punitive Damages: Something for Everyone?, 7 U. ST. Thomas L.J. I, I7 (2009) ("[T]he smart money speculates that Justice Souter joined the dissenters-Justices Stevens, Ginsburg, and Breyer-in voting for vicarious liability."). Regardless, the Ninth Circuit's opinion stands because of Justice Alito's recusal. See Exxon Shipping Co., 554 U.S. at 484 ( "[T] he disposition ... is not precedential on the derivative liability question.").

87 BMW of N. Am., Inc. v. Gore, 5 I 7 U.S. 559,584 ( 1996) ("[An award] cannot be justified on the ground that it was necessary to deter future misconduct without considering whether less drastic remedies could be expected to achieve that goal.").

88 Id. at 593 (Breyer, J., concurring).

89 State Farm, 538 U.S. at 427.

90 See supra text accompanying notes $4 \mathrm{I}, 45-5 \mathrm{I}$.

9I Philip Morris USA v. Williams, 549 U.S. $346,354-55$ (2007).

92 Id. at 351 .

93 Id. at 349 . Technically, the Court's conclusion was based in procedural due process. This 
Concepts of deterrence focusing on under-detection and underenforcement of other potential lawsuits, thus, are not powerful enough to constitutionally justify a punitive damage award. If either optimal or complete deterrence theories survive Philip Morris, they are more limited-considering only the likelihood that the defendant would escape liability for the tortious conduct to that particular plaintiff. ${ }^{94}$ This limited interpretation looks more like a specific deterrence theory because of its focus on the particular plaintiff and defendant. ${ }^{95}$

Some believe, however, that Philip Morris rejects the deterrence purpose of punitive damages as a whole. For example, the substantive portions of the Philip Morris opinion do not include the words "deterrence" or "deter," but include numerous mentions of "punish" or "punishment." 6 And "if juries are not allowed to consider the impact on non-parties when fashioning punitive damages awards, the defendants will almost by definition be under-deterred (because not nearly all of those harmed by the conduct will bring their own lawsuits)." ${ }^{97}$ Similarly, if punitive damages are "limited only to the amount necessary to avenge the moderate harm to the individual plaintiff, a rational defendant ... might continue to engage in the wrongdoing." 98

basis makes little sense, however, given that the defendant received all necessary procedural protections. Many have concluded that the conclusion is more accurately based in substantive due process. See, e.g., Erwin Chemerinsky, Foreword: The Constitution and Fundamental Rights, I 8 U. F LA. J.L. \& Pub. Pol'y, at xi, xii (2007); Keith N. Hylton, Due Process and Punitive Damages: An Economic Approach, 2 Charleston L. Rev. 345, 371 (2008); Lens, supra note 73, at 23; Sheila B. Scheuerman \& Anthony J. Franze, Instructing Juries on Punitive Damages: Due Process Revisited After Philip Morris v. Williams, io U. PA. J. Const. L. I I 47, I 150 , I I 57-59 (2008); Jeremy T. Adler, Comment, Losing the Procedural Battle but Winning the Substantive War: How Philip Morris v. Williams Reshaped Reprehensibility Analysis in Favor of Mass-Tort Plaintiffs, 1 I U. PA. J. Const. L. 729, 745-46 (2009).

94 Markel, supra note 45, at I4 IO (explaining that the cost-internalization calculation survives Philip Morris if the calculation is limited to "the likelihood that the defendant would escape having to pay for that harm" to the specific plaintiff). The Court did not discuss Keith Hylton's gain-elimination theory in Philip Morris even though Professor Hylton presented his theory in his amicus brief. Keith N. Hylton, Reflections on Remedies and Philip Morris, 27 Rev. LiTIG. 9, 28 (2007) ("[T]he ideal approach to punitive damages . . outlined in my amicus brieff] apparently had no effect on the Supreme Court's decision ....").

95 See supra text accompanying note 30.

96 Michael P. Allen, Of Remedy, Juries, and State Regulation of Punitive Damages: The Significance of Philip Morris v. Williams, 63 N.Y.U. ANN. Surv. AM. L. 343, 365 (2008); Colby, supra note 24 , at $457-58$ (explaining that the Court started Philip Morris with the mention of the two purposes of punitive damages but never mentioned deterrence again).

97 Micah L. Berman, Smoking Out the Impact of Tobacco-Related Decisions on Public Health Law, 75 BRooK. L. Rev. I, 57 (2009).

98 Colby, supra note 24, at 458; see Steve P. Calandrillo, Penalising Punitive Damages: Why the Supreme Court Needs a Lesson in Law and Economics, 78 GEo. WVSH. L. Rev. 774, 804-05 (2010) ("IThe Court's decisions] in State Farm and then Philip Morris ... will inevitably dilute the deterrent impact on other similarly situated tortfeasors. Why take socially optimal care if 
Overall, punitive damages' morality-based punishment purpose is prominent in the Court's constitutional analysis. When it comes to constitutional justification, punitive damages' deterrence plays second fiddle.

\section{The Common law-Based Exxon Shipping Co.}

"[T]he Court has tried to avoid taking a position on the appropriate purpose[s] of punitive damages ...."99 The Court's avoidance was proper as its constitutionally-based punitive damages cases were state law tort claims. ${ }^{100}$ In state law tort claims, the Court lacks "the authority ... to alter the rules of the common law" purposes of punitive damages, ${ }^{101}$ or to define a "standard of excessiveness" 102 based on those purposes.

Because tort law is state law, the Court should never have the authority to directly take a position on the appropriate purposes of punitive damages, at least not in something more than dicta. But the Court had this very authority in Exxon Shipping Co. because of the common law basis and the relationship between maritime and tort law. ${ }^{103}$ The Court used the opportunity to explore its ideal system for imposing punitive damages. In doing so, the Court cited Justice Holmes's bad man, a theory that Justice Holmes introduced to separate law and morality.

\section{A. The Maritime (Common) Law Basis}

Factually, Exxon Shipping Co. was based on the Exxon Valdez oil spill. ${ }^{104}$ The jury found the defendant, Exxon Shipping Co., to be reckless in retaining a known relapsed alcoholic to captain a tanker carrying crude oil,

you are only required to pay for a portion of the harm you actually cause?").

99 Geistfeld, supra note 55, at 1113.

Ioo Exxon Shipping Co. v. Baker, 554 U.S. 471, 501-02 (2008) ("Our due process cases, on the contrary, have all involved awards subject in the first instance to state law.").

IoI Pac. Mut. Life Ins. Co. v. Haslip, 499 U.S. I, 42 (I99I) (Kennedy, J., concurring). In Cooper Industries Inc. v. Leatherman Tool Group, Inc., 532 U.S. 424 (2001), the Court could have answered the question regarding whether valuing punitive damages in a way to achieve optimal deterrence was consistent with the damages' deterrence purpose. The Court, however, "decided the constitutional question while trying to sidestep the substantive question about the appropriate purpose of punitive damages." See Geistfeld, supra note 55, at 1114 ; see also Cooper Indus., 532 U.S. at 439 ("[I]t is not at all obvious that even the deterrent function of punitive damages can be served only by economically "optimal deterrence.").

102 Exxon Shipping Co., 554 U.S. at 502.

103 Even though it lacks the authority, "[t]he Supreme Court now casts considerable influence over the development of American tort law even though the Court traditionally left it in the hands of state courts." Donald G. Gifford, The Constitutional Bounding of Adjudication: A Fuller(ian) Explanation for the Supreme Court's Mass Tort Jurisprudence, 44 ARIz. ST. L.J. I I09, 1130 (2012).

104 Exxon Shipping Co., 554 U.S. at 476. 
which caused the plaintiffs' injuries. ${ }^{105}$ The jury awarded the plaintiffs $\$ 287$ million in compensatory damages. ${ }^{106}$ The jury also imposed $\$ 5$ billion in punitive damages, ${ }^{107}$ which the lower courts reduced to $\$ 2.5$ billion by the time the case reached the Supreme Court. ${ }^{108}$

The certiorari question that the Court granted in Exxon Shipping Co. was based in maritime law, which is federal common law. ${ }^{109}$ It asked whether the $\$ 2.5$ billion punitive award "is greater than maritime law should allow in the circumstances." 110 Maritime law uses "the same principles as courts of common law ... in allowing exemplary damages." 111 Thus, the certiorari question essentially asked whether the damages' punishment and deterrence purposes justified the award at issue. Similarly, the common law basis of the certiorari question provided the Court an opportunity to review the general legitimacy of punitive damages and to consider "the desirability of regulating [punitive damages] as a common law remedy." 112

The Court discussed the historical common law purposes of punitive damages: punishing for "extraordinary wrongdoing" and deterring by setting

\footnotetext{
105 Id. at $476-77,480$.

I $06 \mathrm{Id}$. at 480 .

I 07 Id. at $48 \mathrm{I}$.

I $08 \mathrm{Id}$.

I09 Id. at $489-90$.

I Io $I d$. at 476 .
}

II I Lake Shore \& Mich. S. Ry. Co. v. Prentice, I 47 U.S. IoI, I08 (I 893); see also Atl. Sounding Co. v. Townsend, 557 U.S. 404, 4I I (2009) ("The general rule that punitive damages were available at common law extended to claims arising under federal maritime law."); Richard Aaron Chastain, Cleaning Up Punitive Damages: A Statutory Solution for Unguided Punitive-Damages Awards in Maritime Cases, 63 VAND. L. Rev. 813, 822 (2010) ("As a general rule, admiralty courts follow the general trend of the federal courts in nonmaritime cases, viewing punitive damages as serving the dual roles of deterring others from engaging in socially harmful conduct and of punishing-or, in language often used taking 'retribution' against - the defendant."). Maritime and tort law have different limitations on the recovery of compensatory damages, but nothing in the Court's opinion mentions these distinctions-nor should it because limitations on compensatory damages do not control punitive damages' common law purposes.

Even if the law were not the same, the Court's analysis does not look like it is based in maritime law. See Lens, supra note 73, at 24-25 (arguing that Exxon Shipping Co. is not really based in maritime law). See generally id. at 4 (arguing that the Court's predictability analysis in Exxon Shipping Co. also implicates procedural due process concerns). The Court's historical review of punitive damages and their purposes is based in general tort law. Id. at 44-45. Similarly, the studies that the Court used to reach its unpredictability conclusion were state tort law cases. Id. at 25-26; see also Bridgeport Harbor Place 1, LLC v. Ganim, No. Xo6CVo40 I 84523S, 2008 WL 4926925, at * 12 n. I3 (Conn. Super. Ct. Oct. 3 I, 2008) ("It is noted that although the Supreme Court's decision in Exxon Shipping concerned federal maritime law, the Court reached its holding by analyzing and relying on punitive awards in state court civil trials.").

$$
\text { I } 2 \text { Exxon Shipping Co., } 554 \text { U.S. at } 502 .
$$


an example. ${ }^{113}$ The Court confirmed that these common law purposes also control today. ${ }^{114}$ Consistent with these purposes, the Court explained that some defendants are more deserving of punitive damages than others; more blameworthy conduct includes conduct that is intentional or malicious, or conduct undertaken for profit. ${ }^{115}$ And, regardless of reprehensibility, a higher punitive damage award may be justifiable if the defendant's conduct is difficult to detect. ${ }^{16}$

\section{B. The Appearance of Justice Holmes's Bad Man}

Unlike in its constitutional cases, in common law cases the Court has the ability "to unleash its criticism of punitive damages as a policy matter." 117 The common law authority also enables the Court to describe its ideal system of punitive damages. The Court did both.

As for the criticism, the Court discussed that even though "punitive damages overall are higher and more frequent in the United States than they are anywhere else," 118 the problem with them is not "massproduced runaway awards." 119 Instead, the "real" problem is their "stark unpredictability." 20 Using studies of the ratio of punitive to compensatory damages, the Court concluded that "the spread is great, and the outlier cases subject defendants to punitive damages that dwarf the corresponding compensatories." 121 And the factual differences between cases do not explain the outliers. Anecdotally, the Court noted that the same facts produced similar compensatory damage awards in two cases, but very

I $13 \mathrm{Id}$. at $49 \mathrm{I}$. A third historical justification was to compensate for intangible injuries, such as pain and suffering, or mental anguish, which were not included in compensatory damages at the time. Id. at $49 \mathrm{I}-92$. Intangible injuries were eventually included in compensatory damages; for this reason, punitive damages are no longer needed to serve this purpose-nor could this purpose justify their imposition. See id. at 492.

I 14 Id. at 492 .

I 5 Id. at $493-94$.

II 1 Id. at 494 .

117 Catherine M. Sharkey, Commentary, The Vicissitudes of Tort: A Response to Professors Rabin, Sebok \& Zipursky, 60 DePAul L. Rev. 695, 707-08 (201 I).

118 Exxon Shipping Co., 554 U.S. at 496.

119 Id. at 497.

I 20 Id. at 499.

I 2 I Id. at 500. Thus, the Court believed punitive damages to be unpredictable as far as their relationship to the underlying compensatory damages. The authors of the study that the Court used in Exxon Shipping Co. have criticized the Court's consideration of awards with low compensatory damages, which will automatically have a very high ratio between the compensatory and punitive damages-especially because the Court has otherwise stated its approval of a high ratio if the compensatory damages are low. See Theodore Eisenberg et al., Variability in Punitive Damages: Empirically Assessing Exxon Shipping Co. v. Baker, I66 J. Institutional \& TheORETICAL ECON. 5, 12-23 (20 Io). 
different punitive damage awards $-\$ 4$ million in one and zero in the other. ${ }^{122}$

As for the ideal system, according to the Court:

a penalty should be reasonably predictable in its severity, so that even Justice Holmes's "bad man" can look ahead with some ability to know what the stakes are in choosing one course of action or another. And when the bad man's counterparts turn up from time to time, the penalty scheme they face ought to threaten them with a fair probability of suffering in like degree when they wreak like damage. ${ }^{123}$

As for the reforms to achieve this ideal system of imposing punitive damages, the Court suggested a "quantified approach." 124 But it rejected a hard cap because "there is no 'standard' tort or contract injury" 125 and because the legislature is better able to set hard caps and make adjustments for inflation. ${ }^{126}$ The "more promising alternative," according to the Court, is "pegging punitive to compensatory damages using a ratio or maximum multiple." 27 The Court believed that the wisdom of such pegging is demonstrated by the fact that many states have adopted ratio-based caps on punitive damages and Congress also has passed legislation providing treble damages. ${ }^{128}$

Turning to the proper ratio for the punitive damage award in Exxon Shipping Co., the Court rejected a 3:1 ratio because the conduct in retaining a known alcoholic captain was not malicious and egregious, was not undertaken for profit, and would already subject the tortfeasor to regulatory sanctions and compensatory damages. ${ }^{129}$ The Court also rejected a 2:1 ratio because there was no need to provide an incentive to sue; the case involved staggering environmental damage, obviously prompting government reaction and tort lawsuits. ${ }^{130}$

Ultimately, the Court decided that something close to the median 1:1 ratio shown in studies was appropriate ${ }^{131}$ :

122 Exxon Shipping Co., 554 U.S. at 500-0 I.

123 Id. at 502 (citation omitted).

124 Id. at 504. The Court first rejected using more refined jury instructions, finding that they "can go just so far in promoting systemic consistency when awards are not tied to specifically proven items of damage (the cost of medical treatment, say)." Id.

$125 \mathrm{Id}$. at $5^{06 .}$

$126 \mathrm{Id}$.

127 Id.

128 Id. at 507 .

129 ld. at 510-I I.

130 ld. at $5 \mathrm{II}$ ("[I]n this case [there was] staggering damage inevitably provoking governmental enforcers to indict and any number of private parties to sue.").

131 Id. at 512-13 
[A]wards at the median or lower ... roughly express jurors' sense of reasonable penalties in cases with no earmarks of exceptional blameworthiness within the punishable spectrum (cases like this one, without intentional or malicious conduct, and without behavior driven primarily by desire for gain, for example) and cases (again like this one) without the modest economic harm or odds of detection that have opened the door to higher awards. ${ }^{132}$

The Court not only applied the 1:1 ratio to the punitive damage award at issue in Exxon Shipping Co., but it also concluded that the 1:1 would be "a fair upper limit in such maritime cases" with similar factual circumstancesmainly a lower level of reprehensibility but high compensatory damages. ${ }^{133}$

Practically, the Court wants Justice Holmes's bad man and his counterparts to be aware that if they commit reckless conduct likely to cause a substantial amount of damage, they will pay a punitive damage award roughly equivalent to the awarded compensatory damages. It is not surprising to see the Court cite Justice Holmes in Exxon Shipping Co. The Court wanted to increase predictability, and Justice Holmes "waged a lifelong campaign" to make the law more "knowable." 134 But the Court's citation to Justice Holmes's bad man within the punitive damages context is a little strange given the reason that Justice Holmes introduced this character.

\section{The Bad Man Briefly Explained}

Justice Holmes's "bad man" is "arguably his most enduring contribution to jurisprudence." ${ }^{135}$ The bad man first appeared in a speech Justice Holmes gave at the opening of the Boston University School of Law entitled The Path of the Law, which was later reprinted in the Harvard Law Review. ${ }^{136}$ Justice Holmes introduced his bad man as part of his effort to better understand law by separating it from morality, which some have criticized.

1. A Tool to Separate Law and Morality.-Justice Holmes's speech concerned the study of law, which was not surprising given his audience. ${ }^{137}$ Holmes explained that the study of law is a profession because people hire lawyers for advice. ${ }^{138}$ "People want to know under what circumstances" they could be brought into court and be subjected to judicial "judgments and

132 Id. at 513 .

133 Id. (1997).

134 See Thomas C. Grey, Plotting The Path of the Law, 63 Brook. L. Rev. 19, 40-4I

I 35 Marco Jimenez, Finding the Good in Holmes's Bad Man, 79 Fordham L. Rev. 2069, 2073 (201I).

I36 Oliver Wendell Holmes, J., The Path of the Law, IO HaRv. L. Rev. 457 ( 1897 ).

137 Id. at 457 .

I38 Id. 
decrees." 139 A lawyer's role is to predict those circumstances. Law is simply "[t]he prophecies of what the courts will do." ${ }^{140}$ The object of the study of law and the legal profession, then, is prediction. ${ }^{141}$

According to Justice Holmes, one of the things that most interferes with the ability to predict legal outcomes is the confusion of legal and moral ideas. ${ }^{142}$ In fact, Justice Holmes advocated banishing "every word of moral significance ... from the law altogether." ${ }^{143}$ This would reveal laws, which are "[t]he prophecies of what the courts will do in fact, and nothing more pretentious." ${ }^{44}$ To be able to better identify the law, Justice Holmes introduced his bad man:

If you want to know the law and nothing else, you must look at it as a bad man, who cares only for the material consequences which such knowledge enables him to predict, not as a good one, who finds his reasons for conduct, whether inside the law or outside of it, in the vaguer sanctions of conscience. ${ }^{145}$

Justice Holmes applied his theory to tort law. The confusion between morality and law is apparent in the definition of a tort duty; the tendency in defining it is to "fill the word with all the content which we draw from morals." ${ }^{46}$ This is also how the good man would define it. The good man will do the "right thing . . . simply because it is the right thing to do," 147 even if it is not profitable to him. But this perspective does not tell us the "law" as Justice Holmes defined it.

To define and understand a tort duty, according to Justice Holmes, we must examine the bad man's perspective. From his perspective, duty means that "if he does certain things he will be subjected to disagreeable consequences by way of . . . compulsory payment of money." ${ }^{148}$ Essentially, "[i]f you commit a tort, you are liable to pay a compensatory sum." 149

According to Justice Holmes, the bad man's perspective shrinks "the vague circumference of the notion of dury" and makes those same circumferences "more precise." ${ }^{150}$ This precision results because the bad

$139 \mathrm{Id}$.

I $40 \mathrm{Id}$. at $46 \mathrm{I}$.

$141 \mathrm{Id}$.

142 Holmes, supra note 136 , at 459 ("The law is full of phraseology drawn from morals, and by the mere force of language continually invites us to pass from one domain to the other without perceiving it[.]").

$143 \mathrm{Id}$. at 464 .

144 Id. at $46 \mathrm{I}$.

$145 \mathrm{Id}$. at 459 .

$146 \mathrm{Id}$. at $46 \mathrm{I}$.

147 Jimenez, supra note 135 , at 2079.

$148 \mathrm{Id}$. at 2078 (quoting Holmes, supra note 136 , at $46 \mathrm{I}$ ).

I 49 Holmes, supra note $\$ 36$, at 462 .

150 Id. at $461-62$. 
man's perspective removes morality from the calculation. ${ }^{151}$ A tort duty simply means a court's requirement that the bad man pay damages.

The bad man sees the damages that he is required to pay "as nothing more than a tax on conduct." 152 "[R]egarding damages as a tax ... remove[s] any moral onus from the conduct - the income tax doesn't mean that earning an income is reprehensible, and thus the 'tort tax' doesn't mean that tortious conduct is reprehensible." ${ }^{153}$ Thus, the bad man is not confused by whether a duty depends upon his conduct being immoral; he understands that the "duty" obligates him to pay the tax if he chooses to commit the tort. ${ }^{154}$

2. No Concern for Enforcement Probabilities.-The reactions to Justice Holmes's bad man have not been favorable. Generally, the bad man is seen as a "calculating and amoral ... [character] who . . . 'cares only for the material consequences' of his [conduct]." 155 The theory has also been criticized as "advocating a legal system devoid of morality" 156 and as "promot[ing] immoral behavior by encouraging the bad man ... to choose a course of conduct ... according to a cost-benefit analysis in which the bad man chooses to engage in a given activity whenever the benefit of doing so

15I David Luban, The Bad Man and the Good Laweyer: A Centennial Essay on Holmes's The Path of the Law, 72 N.Y.U. L. REv. 1547 , I567 (1997) ("[The bad man concept] is an attempt to eliminate ... a confusion between reading moral words appearing in legal texts in their moral sense, which suggests categorical obligations, and reading them in their legal sense, which (Holmes claims) implies only disjunctive obligations.").

Justice Holmes's theories have greatly influenced tort law. Jimenez, supra note ${ }_{1} 35$, at 2088 (explaining that Holmes's bad man theory "revolutionized" tort law). The most prominent example is the Learned Hand formula for determining whether conduct is negligent. The formula weighs the probability and likely severity of harm that will result versus the costs of taking precautions to avoid causing that harm. If the costs of taking precautions are less than the multiplied harm, the conduct is negligent. This formula enables "the bad man to predict, with a fair degree of accuracy, how a court would rule." Id. at 2095.

Ideally, Justice Holmes would have wanted to make the standard of reasonable care even more specifically defined. See Grey, supra note I34, at 41 ("As part of his project of making the law knowable, Holmes waged a lifelong campaign both as a commentator and judge to replace the standard of reasonable care in the law of accidental injury with a set of more specific rules defining properly safe conduct."); see, e.g., Balt. \& Ohio R.R. Co. v. Goodman, 275 U.S. 66, 70 (1927) (defining a "standard of conduct" to be one where "if a driver cannot be sure otherwise whether a train is dangerously near[,] he must stop and get out of the vehicle"). But see Pokora v. Wabash Ry. Co., 292 U.S. 98, I05 (1934) (rejecting any perception that Goodman defined a standard of conduct).

152 Luban, supra note 151 , at 1565 .

153 Id.

$154 \mathrm{Id}$.

155 Jimenez, supra note 135 , at 2073-74 (quoting Holmes, supra note 136 , at 459).

I56 Id. at 2071-72 (citing Robert W. Gordon, The Path of the Lawyer, I Io HaRv. L. Rev. 1013, $1014(1997))$. 
exceeds the activity's legal cost." 157 A common response to this criticism is that Justice Holmes was not attempting to empower the bad man; instead, he wanted legislatures to understand how the bad man thinks so that they could create penalties that would actually affect the bad man's behavior and, perhaps, turn him good. ${ }^{158}$

Ironically, another criticism of Justice Holmes's bad man argues that he is really not that "bad." Instead, he is "a pretty tame and law abiding bad man." ${ }^{59}$ Even though he evaluates the law in terms of its material consequences, the bad man still accepts the fact that he will have to pay those consequences if he violates the law. ${ }^{160}$ The truly bad man, on the other hand, would focus on the actual likelihood he will have to pay those consequences. ${ }^{161} \mathrm{He}$ would be just as interested in the "enforcement probabilities" as he would be in the "enforcement outcomes." 162

The bad man's failure to consider the likelihood of enforcement probabilities also addresses a weakness in Justice Holmes's prediction theory-that the law is a prophecy of what courts will do. This theory assumes courts have the power to enforce their decisions. ${ }^{163}$ Generally, courts are powerless to enforce most damages awards. ${ }^{164}$ They necessarily rely on other branches of the government to enforce their decisions. Just as the truly bad man would be concerned about enforcement probabilities,

157 Id.

I $5^{8}$ Id. at 2079. Professor Jimenez argues that Justice Holmes's purpose was thus not to celebrate the bad man, but to protect the good man. Id. at 2 I I I.

I59 Luban, supra note $15 \mathrm{I}$, at I57I.

I60 Id.; see also Albert W. Alschuler, The Descending Trail: Holmes' Path of the Law One Hundred Years Later, 49 FLA. L. REv. 353, 368 (1997) ("[S]omeone who murders a solitary homeless person in an alley at 3:00 a.m. is likely to get away with it. The best prediction of what the courts will do in fact is 'nothing.' Presumably the killing is unlawful, yet if Holmes' definition of law were taken literally, it would not be. . . A bad man does not care why legal pronouncements are unenforced so long as they are."); Jill E. Fisch, The "Bad Man" Goes to Washington: The Effect of Political Influence on Corporate Duty, 75 FordHaM L. Rev. 1593, 1597 (2006) ("I do not read Holmes as incorporating the risk of nonenforcement into the bad man's calculation.").

I6I Luban, supra note I51, at I57I; see also Jack M. Beermann, Commentary, Holmes's Good Man: A Comment on Levinson and Balkin, 78 B.U. L. Rev. 937, 944 (1998) ("[I]n addition to the reaction of the courts, the bad man is likely to take into account the probability of detection when deciding whether to obey the law."); Mark Geistfeld, Tort Law and Criminal Behavior (Guns), 43 ARIz. L. REv. 3 I I, 323 (200I) ("A behavioral assumption that realistically accounts for the Holmesian bad man must consider issues of detection and enforcement."); William Twining, Other People's Power: The Bad Man and English Positivism, 1897-1997, 63 BrooK. L. Rev. 189, 207 n.62 ( I997) ("In criminal cases, for example, the "realistic" bad man contemplating a possibly unlawful act would be concerned with the likelihoods of observation, complaint, investigation, detection, decisions to prosecute, plea bargains and pleas, verdicts on questions of fact, procedural and jurisdictional issues, sanctions and so on.").

162 Luban, supra note 151 , at 1571.

I63 See id. at $1576-77$.

164 Id. at 1576 . 
he would also be more concerned about what the sheriff will do instead of the court. ${ }^{165}$

Regardless of the criticisms of Justice Holmes's bad man, the Supreme Court cited the theory in its one unique opportunity to directly address the underlying purposes of punitive damage awards. And with this citation, the Court altered those common law punishment and deterrence purposes.

\section{The Depleted Purposes of Punitive Damages Post- EXXON SHIPPING CO.}

The use of Justice Holmes's bad man as the centerpiece for its ideal punitive damage system "radical[ly] depart[s] from the principles that have governed punitive damages for the last several hundred years." 166 More precisely, the use of Justice Holmes's bad man undermines the damages' common law punishment and deterrence purposes, leaving them without substance.

Punitive damages' traditional punishment purpose is inextricably linked to morality. ${ }^{167}$ Morality justifies the punishment and controls its extent, ${ }^{168}$ and the award itself expresses moral disapproval. ${ }^{169}$ The damages' deterrence purpose has always been less well-defined, leaving open the possibility of it encompassing multiple deterrence concepts.

In Exxon Shipping Co., however, the Court threw this common law tradition out the window. ${ }^{170}$ The punishment purpose of punitive damages is no longer linked to morality, and the Court failed to connect the purpose to any other basis. As for the deterrence purpose, the Court clarified that it has no independent substance, specifically rejecting either an optimal or complete deterrence basis.

I65 Alschuler, supra note I60, at 372 (explaining that the bad man should be more interested in what the sheriff would do than what the courts would do); see also Luban, supra note $15 \mathrm{I}$, at $1576-77$.

I66 See Jimenez, supra note 135 , at 2099-100.

I67 Marc Galanter \& David Luban, Poetic Justice: Punitive Damages and Legal Pluralism, 42 Am. U. L. REv. 1393, 1428 (1993) (explaining that punitive damages are one of the few legal areas that "contravene the reigning impulse to disassociate law from morality"); see also supra Part I.B.I.

I68 See Galanter \& Luban, supra note 167, at I428; see also supra Part I.B.I.

I69 Galanter \& Luban, supra note 167 , at 1428 (characterizing punitive damages as "perhaps the most important instrument in the legal repertoire for pronouncing moral disapproval" and explaining that punitive damages "reinforce the notion of law as a realm of moral achievement").

I 70 And as a reminder, "[r]he Supreme Court now casts considerable influence over the development of American tort law." Gifford, supra note I03, at I 130. 


\section{A. A Punishment Purpose Without Substance}

The Court explained that the issue in Exxon Shipping Co. gave it the chance to explore its "understanding of the place of punishment in modern civil law." 171 Morality appeared only once in that exploration-in Justice Stevens's dissent, where he concluded that "the jury could reasonably have given expression to its 'moral condemnation' of Exxon's conduct in the form of this award." 172

The majority, on the other hand, reconceived the damages' punishment purpose as unrelated to morality. As a part of this reconception, however, the Court did not replace morality with any other principle. Instead, it left the purpose lacking in substance.

1. Rejection of the Morality Basis of the Punishment Purpose.-The Court made morality irrelevant to punitive damages and their punishment purpose in numerous ways. The main way was the Court's citing Justice Holmes's bad man as the centerpiece for the ideal system of imposing punitive damages - a man who appreciates neither moral condemnation nor the stigma traditionally associated with punitive damages. The Court also made morality irrelevant within its own definition of punitive damages and the factors it emphasized (and did not emphasize) in choosing the 1:1 ratio.

\section{a. The Bad Man's Lack of Appreciation of Moral Condemnation}

The Supreme Court has previously described punitive damages as a mechanism by which the jury may express moral condemnation, but in Exxon Shipping Co., it cited a man who does not appreciate morality. A man who does not appreciate morality also does not appreciate the moral condemnation that the jury expresses by imposing a punitive damage award.

Common thought, however, is that punitive damages are one way to reach the bad $\operatorname{man}^{173}$ - the legislators should use punitive and "not just compensatory damages" to affect the bad man's behavior. ${ }^{174}$ The reason that the bad man may be affected by punitive damages is not that he suddenly appreciates the immorality of his conduct. Instead, the unpredictable

171 Exxon Shipping Co. v. Baker, 554 U.S. 47 I, 490 (2008).

$172 \mathrm{Id}$. at 522 (Stevens, J., concurring in part and dissenting in part).

173 Luban, supra note $I_{5}$ I, at 1569 ("The existence of punitive damages . . clearly indicates that the legal system is willing to punish bad men who treat compensation as merely a cost of doing business."); see also Jimenez, supra note 135, at 2097-98 ("With the availability of punitive damages, it seems, the bad man need not be indulged by the good people of this world.").

174 Grey, supra note 134 , at 54 (explaining that to reach the bad man legislatures should look "to criminal penalties, punitive damages, or injunction, not just compensatory damages"). 
damages may reach him because they preclude him from accurately planning out the damages of his tortious conduct, perhaps dissuading him from committing the conduct in the first place. ${ }^{175}$ The Supreme Court's insistence on predictability in Exxon Shipping Co. precludes the use of this strategy of reaching the bad man.

However, even if the bad man could be surprised by the amount, the bad man would not appreciate the moral connotation of the punitive damage award. He sees a punitive damage award just like any orher damage award-as a tax on conduct. ${ }^{176}$ If he injures someone, he already has to pay one tax (i.e., compensatory damages). If his conduct is culpable enough, he will have to pay one additional tax (i.e., punitive damages). ${ }^{177}$ But it is just a tax, which does not communicate any message regarding the immorality of his tortious conduct. ${ }^{178}$ From the bad man's perspective, even "punitive" damages are just part of the price tag of committing tortious conduct.

To use Justice Holmes's terms, the Court's citation to the bad man makes the obligation to pay punitive damages disjunctive. This is what Justice Holmes did with tort duties: "If you commit a tort, you are liable to pay a compensatory sum." "179 But in Exxon Shipping Co., the Court altered this a bit-if you commit a tort, you must pay a compensatory and punitive sum. Notably, Justice Holmes did not apply his theory to criminal law, another field intimately connected to morality. ${ }^{180}$ There, Holmes maintained the morally based categorical prohibition: "Don't do the crime!" 181 The Court

175 See Jimenez, supra note 135 , at 2102 (using the Ford Pinto punitive damage case as an example of a tortfeasor finding its predicted loss "less than reliable in significant part due to the jury's imposition of punitive damages"); Grey, supra note I34, at 54 (arguing that legislators should impose punitive damages for breach of contract because "behavior responds to the incentive effects provided by remedies"). In Exxon Shipping Co., the Court rejected the idea of using unpredictability to punish. Regardless, Justice Holmes's bad man is unaffected by morality-based punishments; he would see punitive damages as just another amount of damages he has to pay regardless of their unpredictability-similar to how the Court defines punitive damages in Exxon Shipping Co. See infra Part III.A.I.c.

I 76 See supra notes I52-53 and accompanying text.

177 This perspective is similar to the Court's definition of punitive damages in Exxon Shipping Co. See infra Part III.A. I.c.

I 78 See supra notes $152-53$ and accompanying text. Similarly, a fine does not carry the same type of moral connotation that a punitive damage award (supposedly) carries. See infra p. 30 and note 200 .

179 Holmes, supra note 136 , at 462; see also Luban, supra note $\mathrm{I}_{51}$, at $\mathrm{I}_{5} 65$.

I80 See Holmes, supra note 136 , at 461 ("Leav[e] the criminal law on one side...."); see also Luban, supra note $\mathrm{I}_{5} \mathrm{I}$, at 1566 .

I81 Luban, supra note $15 \mathrm{I}$, at 1566 . Professor Luban points to two possible reasons Justice Holmes saw criminal law differently. The first is that the bad man would obviously view imprisonment differently-as something more than a mere tax on conduct. Id. at 1566 . The second is that Justice Holmes believed in the "hereditarian notion of criminality," meaning that punishment would not deter criminals from committing crimes. Id. Justice Holmes obviously did not apply his bad man theory to punitive damages. It is possible that his belief in the hereditarian notion motivated this non-application. 
has consistently pointed to the similarities in the purposes of criminal law and punitive damages, ${ }^{182}$ but applied the bad man's non-morality-based disjunctive outlook to punitive damages.

\section{b. The Bad Man's Immunity to Any Punitive Damages Stigma}

Related to the jury's expression of moral condemnation is the stigma traditionally associated with punitive damages. This stigma is what separates compensatory and punitive damages in tort:

[U]nlike the term "punitive damages," the term "compensatory damages" does not itself connote blameworthy conduct by the defendant.

To award punitive damages, on the other hand, the jury must find that the defendant acted maliciously, in "wanton and reckless disregard for the rights of others," with "flagrant indifference" to the rights of others, or in an "outrageous" manner. The word "punitive," denoting punishment for wrongdoing, is used to describe the award .... . Thus, a punitive damages award, unlike a compensatory award, seems always to constitute a "badge of disgrace" and to jeopardize the defendant's good name, reputation, honor, and integrity. ${ }^{183}$

The stigma punishes the tortfeasor independently and ensures that punitive damages punish in a way other than just requiring the tortfeasor to write a larger check.

182 Exxon Shipping Co. v. Baker, 554 U.S. 471, 504-06 (2008).

183 Malcolm E. Wheeler, The Constitutional Case for Reforming Punitive Damages Procedures, 69 VA. L. Rev. 269, 28 I-82 (1983) (footnotes omitted); see also Pac. Mut. Life Ins. Co. v. Haslip, 499 U.S. I, 54 (1991) (O'Connor, J., dissenting) ("[T]here is a stigma attached to an award of punitive damages that does not accompany a purely compensatory award. The punitive character of punitive damages means that there is more than just money at stake."). But see Robert E. Riggs, Constitutionalizing Punitive Damages: The Limits of Due Process, 52 Онго St. L.J. 859,879 ( I 991) ("Claims of any significant stigma are not very convincing ...."). Professor Kahan did not draw an analogy between shaming penalties and the stigma resulting from punitive damages in his article, What Do Alternative Sanctions Mean?, 63 U. CHI. L. Rev. 59I ( I 996), but others have. See Michael Abramowicz, A Compromise Approach to Compromise Verdicts, 89 CALIF. L. Rev. 23I, 280 n. 89 (200I) (noting that shame sanctions are generally associated with criminal law, but a similar stigma can result from punitive damages); Galanter \& Luban, supra note 167 , at 1444 ("[T]he aim of retributive punishment is to inflict expressive defeat on wrongdoers. They are to be humbled, in order to repudiate publicly the moral falsehood implicit in their behavior. Punishment on this view, must be public and must attempt to shame the wrongdoer."); Thomas Koenig \& Michael Rustad, "Crimtorts" as Corporate Just Deserts, 3 I U. Mich. J.L. Reform 289, 3 I6 (I998) ("Corporations often fear the adverse publicity that accompanies punitive damages ... far more than the monetary costs. Being publicly labeled as an endangerer of the public welfare is the functional equivalent of a shaming ceremony for individuals."); of. Andrea A. Curcio, Painful Publicity-an Alternative Punitive Damage Sanction, 45 DePaul L. Rev. 341, 357 (I996) (explaining that a lack of publicity of imposed punitive damage awards hurts the damages' ability to punish) "Public condemnation and its attendant sense of shame are integral to the concept of exacting retribution." Id. 
Any such stigma, ${ }^{184}$ however, does not exist in the theoretical world of Justice Holmes's bad man because it does not create any material consequences. Again, the bad man defines the law based on its material consequences. ${ }^{185}$ And the alleged stigma associated with punitive damages does not create any material consequence that would affect the bad man.

For comparison's sake, the stigma associated with a criminal conviction creates material consequences. ${ }^{186}$ For instance, a convict may have difficulty obtaining employment as criminal convictions often have to be disclosed when applying for employment. ${ }^{187}$ Similarly, criminal convictions stay on a defendant's record, ${ }^{188}$ and convicted felons lose certain civil rights, like the right to vote. ${ }^{189}$

No similar material consequence results from the stigma that accompanies a punitive damage award. Theoretically, the punitive damages' "badge of disgrace" impairs the bad man's reputation and makes members of the community want to avoid dealing with the bad man. ${ }^{190}$ But it is difficult to turn this theoretical consequence into a material one, which is the only type of consequence that would affect the bad man.

The damage award in a defamation claim supports this argument. A defamation claim compensates harm based on a decreased reputation. ${ }^{191}$ Demonstrating actual harm or damage that would also constitute a material consequence of a decreased reputation-for example, a loss of customersis notoriously difficult. ${ }^{192}$ To alleviate this difficulty, defamation law presumes harm for some defamatory statements, mostly in cases where the harm or damage is obvious despite the difficulty in proving it. ${ }^{193}$ This does not apply in all defamation cases. For instance, harm is not presumed when

I 84 Arguably, this stigma does not really exist anymore partly because of tort reform efforts. See infra Part III.A. I.e.

185 Holmes, supra note $\mathrm{I} 36$, at 459.

I 86 Wheeler, supra note I 83 , at $283-84$.

I 87 Id. at 283 .

188 Riggs, supra note 183 , at 889 .

189 Wheeler, supra note 183 , at 283 . Professor Wheeler also discusses other differences between the material consequences of a criminal conviction and a punitive damages award: I) a criminal conviction can be used for impeachment purposes, but a punitive damage award cannot; 2) convicted felons lose certain civil rights, but no such forfeiture occurs with punitive damages; 3) lawyers can be disbarred for criminal convictions, but not punitive damage awards; and 4) prior criminal convictions may be the basis for increased criminal sanctions in later cases, but punitive damages awards lack this power. Id. at $283-84$.

190 Id. at $28 \mathrm{I}-82$.

I9I DoBbs, supra note $20, \S 7.2(2)$, at 628 .

I 92 Id. (explaining that presumed damages were the "central means by which" plaintiffs were able to obtain relief).

I 93 Id. $\$ 7.2(3)$, at 628-29 (explaining that presumed damages were always available for libel, but with slander, only certain subject matter qualified for presumed damages). 
the defamatory statements accuse the defendant of general immoral but non-criminal conduct. ${ }^{194}$

The notorious difficulty of establishing actual harm or damages in a defamation claim also shows that any alleged reputational harm resulting from a punitive damage award likely does not affect the defendant materially. Simply put, it is difficult to show actual harm caused by a damaged reputation. Even defamation law refuses to presume harm when the defamatory statement accuses the defendant of immoral conduct-the same message that the jury sends when it imposes punitive damages. There may be general sentiment that a punitive damage award would hurt the defendant's reputation, but this sentiment is not a material consequence. And without a material consequence, like a loss of customers, the bad man will not be punished or otherwise affected by any such stigma traditionally associated with punitive damages.

\section{c. No Reference to Morality in Defining Punitive Damages}

According to the Court in Exxon Shipping Co., a punitive damage award is just the amount that the defendant will have to pay if he commits a tortious act. ${ }^{195}$ This is the definition the Court uses to accompany its conclusion that even Justice Holmes's bad man is entitled to some idea of what he will pay before committing a tortious act.

What is notable in this definition is what is missing: any recognition of the punishment purpose of punitive damages, or, similarly, the immorality of the defendant's conduct and how it deserves punishment. The Court's definition does not communicate to the defendant that the contemplated tortious conduct is reprehensible or immoral, or that the defendant will be "punished" in some extra way if he commits the contemplated tortious conduct. Instead, it simply communicates the extra consequence if the bad man opts to commit the conduct. ${ }^{196}$

The Court's "just the amount the defendant will have to pay" definition also does not differentiate between compensatory and punitive damages;

194 Id. $\$ 7.2(3)$, at 629 ("At some relatively recent time, a disputed number of common law courts began to require proof of pecuniary loss in cases of 'libel per quod.' .. . [This] category included cases in which the defamatory content of the publication could not be recognized by a mere reading of the publication, that is, cases in which some added information was required to see that the statement defamed someone.").

195 Exxon Shipping Co. v. Baker, 554 U.S. 471, 502 (2008) ("[A] penalty should be reasonably predictable in its severity, so that even Justice Holmes's 'bad man' can look ahead with some ability to know what the stakes are in choosing one course of action or another.").

196 This focus on the consequence is similar to the disjunctive obligations that Justice Holmes outlines. See Oliver Wendelle Holmes, J., The Path of Lav, 10 Harv. L. Rev. 457, 462 (1897); David Luban, The Bad Man and the Good Laveyer: A Centennial Essay on Holmes's The Path of Law, 72 N.Y.U. L. Rev. 1547, 1565 (1997). 
it could just as easily cover compensatory damages. ${ }^{197}$ Both are just damage awards that the defendant will have to pay if he commits tortious conduct. The Court negates what differentiates punitive damages-the relevance of morality and stigma.

\section{d. No Consideration of Morality in Choosing the 1:1 Ratio}

Mainly, the factors that the Exxon Court used to reduce the punitive damage award and choose the 1:1 ratio were: 1 ) the defendant's previous payment of civil fines, 2) the high compensatory damage award, and 3) the perceived low level of reprehensibility of the conduct. ${ }^{198}$ None of these factors, as the Court describes them, should be used to evaluate whether an award is consistent with the damages' common law punishment purposeat least not if that punishment purpose is based in morality. ${ }^{199}$

Regarding the first factor, payment of government fines, "punishment" by fine and by punitive damages differ. The standard for imposing a fine may not be morally based. This is also why fines are not thought to express moral disapproval: "[T]hey are open to the interpretation that society is attaching a price tag to, rather than prohibiting, the punished behavior: we cannot condemn someone morally for buying what we are willing to sell, even if we are charging a high price for it." ${ }^{200}$ For the same reason, there is no chance a fine could stigmatize a defendant in the same way punitive damages are thought to do. Moreover, even if fines did express moral disapproval, they still differ because the fines do not express a jury's

197 The Court had previously differentiated between the two based on the jury's perspective: compensatory damages are based on the "jury's assessment of the extent of a plaintiff's injury ... whereas its imposition of punitive damages is an expression of its moral condemnation." Cooper Indus. v. Leatherman Tool Grp., Inc., 532 U.S. 424, 432 (2001).

I 98 The Court first rejected a 3:1 ratio because the conduct "expos[ed] the tortfeasor to certain regulatory sanctions and inevitable damages actions," resulted in "substantial recovery for substantial injury," and was merely reckless. Exxon Shipping Co., 554 U.S. at 510-11. The Court also mentioned the high compensatory damage award when rejecting a possible 2: I ratio, choosing the I:I ratio, and confirming the propriety of the I:I ratio based on its conclusion that, constitutionally, a "single-digit maximum is appropriate" when compensatory damages are substantial. Id. at 514-15. The Court also rejected a 2: I ratio because there was no need to incentivize private litigation because the "staggering damage inevitably provok[ed] governmental enforcers to indict and any number of private parties to sue." Id. at 5II. See discussion infra Part III.B. I.c).

199 True, the Court mentions that a I:I ratio "roughly express[es] jurors' sense of reasonable penalties" in cases involving merely reckless conduct and a substantial compensatory damage award. Exxon Shipping Co., 554 U.S. at 474 . But this language does not mirror the traditional language used to describe the moral condemnation/punishment purpose of punitive damages. At the very least, the Court could have concluded that jurors use a I:I ratio to express their moral disapproval of the defendant's conduct when the conduct is merely reckless but causes substantial damage.

200 Dan M. Kahan \& Eric A. Posner, Shaming White-Collar Criminals: A Proposal for Reform of the Federal Sentencing Guidelines, 42 J.L. \& EcoN. 365, 380-8I (I999). 
moral disapproval. And the defendant's previous payment of a fine would not necessarily lessen the jury's moral disapproval; paying a fine after the conduct does not make the initial conduct less immoral. In all, the government's imposition of fines and the defendant's payment of the same do not make the defendant's conduct less deserving of punitive damages' morality-based punishment, but the Court uses this factor to reduce the award. ${ }^{201}$

Similarly, the high compensatory damage award does not make the defendant's conduct less deserving of morality-based punishment. The availability and measurement of compensatory damages does not depend on morality. The jury cannot express its moral condemnation through the compensatory damage award; it cannot award more because the defendant's conduct was malicious as opposed to reckless, especially not in a case based on economic compensatory damages like Exxon Shipping Co. And like a fine, there is no chance that the compensatory damage award will create a punishing stigma. ${ }^{202}$ Again though, the Court used this factor to reduce the award.

Unlike the other factors the Court considered in choosing the 1:1 ratio, the last factor, the level of reprehensibility, can be relevant to the damages' common law punishment purpose. Generally, reckless conduct is less immoral than malicious or purposeful conduct, making a less severe punishment appropriate. But the way the Court used this factor does not acknowledge the common law's emphasis on morality.

Just as it held in its constitutional review of punitive damages, the Court assumed that because the conduct was "reckless," reduction of the punitive damage award was appropriate. In common law review, however, a finding of recklessness should not automatically require reduction because it does not necessarily mean less immorality. The conduct in Exxon Shipping Co. is a perfect example of this because it lacks an intentional version. ${ }^{203}$ Luckily, there is little chance of a defendant intentionally causing one of

201 The amount of related public penalties is relevant to optimal deterrence, which mandates subtracting the amount of the public penalties from the level of punitive damages. Polinsky \& Shavell, supra note 30, at 927 ("If punitive damages are not reduced from the amount implied by our formula to reflect public penalties borne by the defendant, the defendant's combined private and public payments would result in his expected payments exceeding the harm done.").

202 See supra Part IV.A.I.b.

203 This is another reason why the level of reprehensibility constitutional guidepost is difficult to apply. Originally, the Supreme Court labeled this guidepost as the most important. BMW of N. Am., Inc. v. Gore, 517 U.S. 559, 575 (1996). That importance appears to have waned, likely because of the difficulty in applying it. Even though intentional conduct should be punished more severely than reckless conduct, the guidepost does not quantify the proper severity. And if conduct lacks an intentional version, does that automatically mean the conduct should be punished less than other, unrelated intentional conduct? Should reckless conduct causing extreme economic damage, like the conduct in Exxon Shipping Co., really be punished less severely than intentional conduct causing minimal economic damage? 
the greatest environmental disasters ever. ${ }^{204}$ The conduct will only ever be reckless. Thus, although reckless, the defendant's conduct in Exxon Shipping Co. was at its most immoral possibility. The jury's level of moral disapproval may reasonably have been at its highest level. ${ }^{205}$ The Court did not entertain this possibility and instead apparently assumed that a recklessness categorization mandates reduction.

Although it did not admit it, it is possible that the Court simply disagreed with the original jury's determination of the immorality of the conduct; ultimately, the Court reduced the punitive damage award to about one tenth of what the jury imposed. 206 This trumping of the jury's judgment, however, would be inappropriate, especially given the possible reasonableness of that judgment. ${ }^{207}$ As the Court has explained, the amount of a punitive damage award is left to the jury's discretion, and the trial court reviews that amount to ensure it is reasonable. ${ }^{208}$ The appellate court then reviews the trial court's determination for an abuse of discretion. ${ }^{209}$ There is no room within this standard of review for the Court to substitute its own conclusions on the morality of the defendant's conduct. ${ }^{210}$ The Court certainly does not admit to this substitution, if that is what occurred. The majority also did not identify the standard of review it used in choosing the 1:1 ratio.

A common law review of a punitive damage award should evaluate whether an award is consistent with the damages' common law purposes, including the morality-based punishment purpose. The Court purported to perform a common law review in Exxon Shipping Co., but it used three factors that are not relevant to whether the defendant's conduct was

204 DoBrs, supra note 20, § 3. I I (3), at 325 ("Owners of oil tankers do not really desire to discharge their valuable commodity into the public waters; this is not a profit-making activity for them.").

205 See Calandrillo, supra note 98, at 807 ("The fact that Exxon knew about Captain Hazelwood's history of alcoholism but did little about it evidently did not sit well with the jury, or with most Americans for that matter.").

206 Id. at 79I. The Court emphasized that it treated the defendant's conduct "categorically as one of recklessness, for that was the jury's finding," and that it did not mean to suggest that the conduct was "less than reprehensible." Exxon Shipping Co. v. Baker, 554 U.S. $471,510 \mathrm{n} .23$ (2008).

207 Justice Stevens affirmed the award in his dissent using an abuse of discretion standard of review. Exxon Shipping Co., 554 U.S. at 522 (Stevens, J., concurring in part and dissenting in part).

208 Pac. Mut. Life Ins. Co. v. Haslip, 499 U.S. I, 15 (199I).

209 Cooper Indus. v. Leatherman Tool Grp., 532 U.S. 424, 433 (200I) ("If no constitutional issue is raised, the role of the appellate court, at least in the federal system, is merely to review the trial court's 'determination under an abuse-of-discretion standard."'). But see id. at 437 ("[T]he level of punitive damages is not really a 'fact' 'tried' by the jury.") (citations omitted).

210 This type of trumping of the jury's judgment makes sense in a constitutional review of a punitive damage award, where the standard of review is de novo, but not in a review for abuse of discretion. See id. at 434-36. 
immoral and thus deserving of punishment. Effectively, the Court negated morality's relevance to punitive damages' punishment purpose.

\section{e. The Court's Previous De-emphasis of Morality}

The Court's analysis in Exxon Shipping Co. is not the first time it has deemphasized the role of morality within punitive damages. Long before Exxon Shipping Co., the Court's criticism and reduction of punitive damage awards helped diminish the effect of any morality-based stigma associated with punitive damages.

Justice O'Connor was one of the most vocal critics of punitive damages in the Court's early cases reviewing the constitutionality of punitive damage awards. ${ }^{211}$ As early as 1989 , Justice O'Connor stated that punitive damage awards were "skyrocketing," and noted "[t]he threat of such enormous awards has a detrimental effect on the research and development of new products." 212 She also warned that juries might use the damages to "target unpopular defendants, penalize unorthodox or controversial views, and redistribute wealth," as well as to inflict "[m]ultimillion dollar losses... on a whim." ${ }^{213}$ She was especially concerned about awards imposed on corporations because juries were unlikely to view them "with much sympathy" and might seek to redistribute wealth from large, especially out-of-state, corporations to the needy plaintiff. ${ }^{214}$

The tort reform movement espouses similar criticism. ${ }^{215}$ The focus of the current tort reform movement is "how lawsuit abuse by ordinary Americans [is] creating a tort tax on businesses impacting all Americans."216 It frames plaintiffs' trial lawyers as "seeking only to redistribute wealth from corporations to greedy widows and children." 217 It also highlights the frivolousness of claims and how irresponsible juries are biased against

2 I I Hubbard, supra note 32 , at 396 ("Justice O'Connor and the other members of the majority simply accepted, without any critical analysis, the rhetoric used by the 'tort reform' movement in its push for a wide range of changes in tort law to favor defendants in tort litigation.").

212 Browning-Ferris Indus. of Vt. v. Kelco Disposal, Inc., 492 U.S. 257, 282 (1989) (O'Connor, J., concurring in part and dissenting in part).

213 Haslip, 499 U.S. at 43 (O'Connor J., dissenting) (criticizing the lack of procedural protections in the imposition of punitive damages).

214 TXO Prod. Corp. v. Alliance Res. Corp., 509 U.S. 443, 49 I (1993) (O'Connor, J., dissenting).

215 See Michael L. Rustad, The Endless Campaign: Horv the Tort Reformers Successfully and Incessantly Market Their Groupthink to the Rest of Us, in Materials ON TORT Reform 33, 36-38 (Andrew F. Popper ed., 20 Io). Professor Rustad labels the current tort reform movement "one of the most successful social movements in American history." Id. at 34.

216 Id. at 36.

217 Id. at 37; Joan Vogel, The Tort Reform Movement as a Teaching Vehicle, in Materials on Tort Reform 26, 26 (Andrew F. Popper ed,, 2010) ("The Tort Reform Movement has also convinced many Americans that tort remedies need to be scaled back to prevent greedy plaintiffs' attorneys and undeserving plaintiffs from wrecking the American economy."). 
wealthy defendants and "bestow windfalls on undeserving plaintiffs." 218 The current tort system "costs an alarming drain on national wealth ... stifles enterprise and innovation .... and undermine $[s]$ the international competitiveness of American businesses."219

In addition to its criticism of punitive damage awards, the Court has dramatically altered the constitutional review of those same awards in the past twenty years. ${ }^{220}$ In every case in which the Court has applied its constitutional guideposts, the Court has either reduced or ordered the reduction of the punitive damage award at issue. ${ }^{221}$

This criticism and reduction of punitive damages has affected the condemnatory power of a punitive damage award.222 The power of an award depends on the public's reaction to it. ${ }^{223}$ If the public does not think less of a defendant because it is forced to pay punitive damages, the award loses much of its power. No longer does the public question the defendant's integrity like the traditional stigma assumes. ${ }^{224}$ Instead, the public questions the legitimacy of the punitive damage award imposed.

218 Rustad, supra note 215 , at 38 .

$219 \mathrm{ld}$.

220 See supra Part II.C. I (detailing the Court's constitutional guideposts).

22 I See State Farm Mut. Auto. Ins. Co. v. Campbell, 538 U.S. 408, 428-29 (2003); BMW of N. Am., Inc. v. Gore, 5 I 7 U.S. 559, 585-86 (1996). Like the Court, legislatures have been active in reforming punitive damages. A total of twenty-six states have set caps on punitive damages. See Thomas J. Miceli \& Michael P. Stone, The Determinants of State-Level Caps on Punitive Damages: Theory and Evidence I2-13, (Univ. of Conn. Dep't of Econ., Working Paper No. 2010-25, 2010), available at http:/www.econ.uconn.edu/working/2010-25.pdf (indicating that twenty-four states have passed punitive damage caps); see also S.C. CodE ANN. § I532-530(A) (Supp. 201 I) (capping punitive damages at the greater of three times the amount of compensatory damages or \$500,000); TeNN. CoDE ANN. \$ 29-39-104(a)(5) (2012) (capping punitive damages at the greater of two times the amount of compensatory damages or $\$ 500,000)$.

222 See L. Song Richardson, When Human Experimentation Is Criminal, 99 J. Crim. L. \& Criminology 89, 114-I5 (2009) ("[P]unitive damages are the subject of negative portrayals in the media as a result of the tort reform movement. The archetype stories of frivolous lawsuits that are rewarded by out-of-control juries paint punitive damages awards as abuses of the legal system."); Id. at 115 ("If reduced, the resulting damages may no longer humble and shame the offender. Indeed, the reduction may even vindicate the wrongdoer."). This does not mean that the Court's reductions were improper, just that even a constitutionally required reduction of a punitive damage award affects the public's perception of the defendant.

223 Wheeler, supra note 183 , at 281-82. But see Note, Shame, Stigma, and Grime: Evaluating the Efficacy of Shaming Sanctions in Criminal Law, 116 Harv. L. REv. 2186, 2194-95 (2003) (explaining that even if the public is not aware that the shamed offender has been shamed, he "nonetheless constantly faces the possibility that some know his 'true' status.").

224 Another reason that punitive damages likely lack the stigma today that they may have once had is the commercial context in which punitive damages are most commonly awarded. "[T] he beneficiaries of punitive damages are often business plaintiffs suing business defendants." Neil Vidmar \& Mirya Holman, The Frequency, Predictability, and Proportionality of Jury Awards of Punitive Damages in State Courts in 20o5: A New Audit, 43 Sufrolk U. L. Rev. 855, 866 (2010); see also DobBs, supra note $20, \S 3.1 \mathrm{I}(\mathrm{I})$, at 317 ("In the $1980 \mathrm{~s}$, most punitive awards 
This change is evident in the public's reaction to one of the most famous cases highlighted in the tort reform movement: Liebeck v. McDonald's. ${ }^{225}$ McDonald's had received over 700 complaints from people burnt by its coffee, but made no adjustment to the temperature-even though it was hot enough to cause third-degree burns within three seconds of touching and was hotter than coffee served by other fast-food and coffee restaurants. ${ }^{226}$ When someone who suffered third-degree burns due to exposure to the coffee sued, the jury imposed a punitive damage award based on the profits McDonald's earned from just two days of selling its coffee. ${ }^{227}$

What was the public's reaction to the jury's moral condemnation of McDonald's conduct? That the jury unfairly imposed a $\$ 2.9$ million punitive damage award on McDonald's for a clumsy old woman spilling coffee on herself. 228 The public was not outraged at McDonald's for its immoral conduct. McDonald's integrity or honor was not damaged, and no stigma materially affected McDonald's. ${ }^{229}$ Instead, public reaction actually favored McDonald's ${ }^{230}$ - the opposite of what the traditional moralitybased punishment purpose intended.

seem to have been made in economic tort cases, such as cases of wrongful discharge, bad faith business dealings, or interference with contract."). The economic context of these punitive damage awards tends to downplay any moral stigma attached to an award; cases between two businesses are seen just as business conflicts.

225 Liebeck v. McDonald's Rests., P.T.S., Inc., No. GV-93-024I9, I995 WL 360309 (N.M. Dist. Ct. Aug. I8, I994), vacated sub nom. Liebeck v. Rests., I 994 WL I6777704 (N.M. Dist. Ct. Nov. 28, I994); see Rustad, supra note 215 , at 33 ("Tort reformers are not embarrassed to cite the McDonald's hot coffee case as an example of random, 'jackpot justice.' The case became familiar to the public as an example of a tort world out of control.").

226 Vogel, supra note 217 , at 27.

227 Andrea Gerlin, A Matter of Degree: How a Jury Decided That a Coffee Spill Is Worth \$2.9 Million, Wall ST. J., Sept. I, I994, at A I .

228 See Vogel, supra note 217 , at 28.

$229 \mathrm{McDonald}$ 's did not suffer any appreciable drop in its stock price around the time of the punitive damage verdict. At the end of July 1994, its stock price was \$1 3.56. McDonald's Corp., MSN MoNex, http://investing.money.msn.com/investments/charts/?symbol=MCD\#sy $\mathrm{mbol}=\mathrm{MCD} \&$ event $=\& \mathrm{BB}=\mathrm{off} \& \mathrm{CCI}=$ off $\& \mathrm{EMA}=\mathrm{off} \& \mathrm{FSO}=\mathrm{off} \& \mathrm{MACD}=\mathrm{off} \& \mathrm{MFI}=\mathrm{off} \& \mathrm{P}$ $\mathrm{SAR}=$ off $\& \mathrm{RSI}=$ off $\& S M A=$ off $\& S S O=$ off $\&$ Volume $=$ off \&period=Custom\&linetype $=$ Line $\& s$ cale $=$ Auto $\&$ date $=6 / 1 / 1994,8 / 1 / 1995 \&$ comparelist $=\$$ indu, $\$$ compx, $\$$ inx (last visited Apr. I5, 2013). The verdict was announced on August I8, I994. Liebeck, I995 WL 360309, at *I. At the end of August, McDonald's stock price was \$I4.13. The stock price did drop to \$13.19 at the end of September, but it rebounded to $\$ 14.44$ at the end of October and ascended to over $\$ 16.00$ by the end of January 1995 and over $\$ 19.00$ by the end of July I 995 . Id. Similarly, McDonald's did not experience any drop in its quarterly revenue. McDonald's Corp., Annual Report (Form IO-K) (Mar. 29, I995). Its quarterly revenue, in millions of dollars, was as follows: $\$ 2,029.30$ in June 1994, $\$ 2,225.40$ in September 1994, and $\$ 2,270.10$ in December 1994. Id.

230 See, e.g., A Hot Issue, Tea \& Coffee Trade J., Sept. 1, 1995, available at I995 WLNR 5603513 ("Public opinion polls show that most Americans felt the McDonald's case was frivolous."); Gerlin, supra note 227, at AI (indicating both that public opinion was on McDonald's side and that polls have shown a majority of Americans were outraged by the $\$ 2.9$ million verdict). 
2. Failure to Replace the Substance of the Damages' Punishment Purpose."Punishment is not just a way to make offenders suffer; it is a special social convention that signifies moral condemnation." ${ }^{231}$ Without the connection to morality, it is not clear that punitive damages even constitute "punishment."232

Even if punitive damages still constitute a "punishment," however, without morality, there is no basis for imposing that punishment. Pretend "every word of moral significance" was banished from the punitive damages field. ${ }^{233}$ Without words like "malice," there is no definition of the type of conduct that deserves punishment. Similarly, there is no definition of when more severe punishment is appropriate. The Court's analysis removes words like "malice" from the punitive damages equation, but it does not replace those words with anything else-leaving no standard for imposing the punishment.

Similarly, even if punitive damages still constitute a "punishment," how exactly the damages punish is unclear given the loss of the stigma. ${ }^{234}$

23 I Kahan, supra note 24 , at 593. In his article What Do Alternative Sanctions Mean? Professor Kahan advocated shaming penalties as an alternative to imprisonment. See id. at 635. But see Dan M. Kahan, What's Really Wrong with Shaming Sanctions, 84 Tex. L. Rev. 2075, 2075 (2006) (recanting his former support for criminal shaming penalties as an alternative to imprisonment).

232 See Richardson, supra note 222, at 107 (summarizing philosopher Joel Feinberg's well-known formulation of punishment, which defines a "necessary condition of punishment" as one that "expresses censure, judgment, and disapproval in a socially conventional matter"); see also Kahan, supra note 24, at 636 ("[T] to shaming penalties as the infliction of shame itself."). Professor Kahan explained that a shaming penalty still expresses shame even if the offender does not experience shame:

The public's realization that not all offenders view such punishments as
disgraceful, however, does not diminish the resonance of either shaming penalties
or imprisonment as symbols of the community's moral disapproval. If anything, the
perception that the offender is not shamed by what is commonly understood to be
shameful would reinforce onlookers' conclusion that he is depraved and worthy of
condemnation.

Id.

233 Holmes, supra note I 36 , at 464. For example, Justice Holmes pointed to the word "malice" within defamation. Id. at 463. Malice carries with it moral connotations, but those evil intent type connotations have nothing to do with the meaning of malice within defamation, which asks only whether the defendant was aware of the falsity of the statement. Id.

Although he does not address it, it is possible that Justice Holmes would not advocate banishing words of moral significance from the punitive damage context because they properly refer to the defendant's mindset. Because the words refer strictly to the defendant's mindset, these references may not have troubled Justice Holmes. See id. Thus, his concern about confusing morality and the law may not apply to the use of "malice" within punitive damages law. If the Court was assuming this non-application when it cited Justice Holmes's bad man in Exxon Shipping Co., it did not explain so.

234 Even if an offender is not shamed by a shaming penalty, the shaming penalty is still effective because it creates a stigma. Kahan, supra note 24 , at $636-37$ (describing that the expression of moral condemnation alone is valuable because it translates into a "degradation penalt[y]" and "lower[s] the offender's social status within that community"). "It is not a 
Damages lacking any moral connotation will not cause the public to look at the defendant any differently. Regardless though, the Court refers to a tortfeasor who, guaranteed, will not be affected by a stigma; Justice Holmes's bad man, the centerpiece of the Court's ideal punitive damages, does not appreciate any morally based stigma that fails to create a material consequence.

Under the Court's conception of punishment, punitive damages are basically a fine-another check for the bad man to write after committing tortious conduct, ${ }^{235}$ but with no clear aim in its imposition. This is a far cry from the traditional thought that punitive damages reflect moral condemnation.

\section{B. A Hollow Idea of Deterrence}

Before Exxon Shipping Co., the Court discussed punitive damages' deterrence purpose in vague terms and determined it insufficient to justify the amount of a punitive award. ${ }^{236}$ Exxon Shipping Co. gave the Court an opportunity to explore the common law deterrence purpose and give it some independent substance. . $^{237}$

The Court, however, declined to give it any substance, much less independent substance. In fact, the Court clarified that the purpose does not include optimal and complete deterrence by assuming away issues related to under-detection and under-enforcement and by imposing punitive damages despite guaranteed liability. More than ever, punitive damages' deterrence purpose rings hollow.

1. Ultimate Rejection of Optimal and Complete Deterrence.-Before Exxon Shipping Co., the Court did not seem too keen on the use of punitive damages to achieve either optimal or complete deterrence. Both theories

condition of a successful degradation ceremony that it induce any particular belief or emotion on the part of the offender." Id. at 636. However, Justice Holmes's bad man is immune to any type of stigma resulting from punitive damages because the stigma fails to create a material consequence. See supra Part IV.A. I.b.

235 See Dan M. Kahan \& Eric A. Posner, Shaming White-Collar Criminals: A Proposal for Reform of the Federal Sentencing Guidelines, 42 J.L. \& EcoN. 365, 380-8I (I 999) (discussing that fines are not morally based).

236 See discussion supra Part I.C.2.

237 See Colby, supra note 24 , at $458 \mathrm{n} .292$ ("That the Court has not abandoned the deterrence rationale for punitive damages is clear from its opinion in Exxon Shipping Co. ...."). The Court's very mention of Justice Holmes hints at an economics-based deterrence focus; in the same speech in which Justice Holmes introduced his bad man, he explained that "every lawyer ought to seek an understanding of economics." See Holmes, supra note 136, at 474; see also Calandrillo, supra note 98 , at 820 (advocating that the Court reject approaches to punitive damages based on "gut reactions ... in response to morally reprehensible behavior" as "legal legends like Oliver Wendell Holmes[] have recognized that we need to separate emotion from the law in order to create law that makes sense"). 
attempt to fix the problems of under-detection and under-enforcement by increasing punitive damages based on the chances of escaping liability, which appears unconstitutional after Philip Morris. ${ }^{238}$

Exxon Shipping Co. clarifies that, even if constitutional, both theories are inconsistent with the damages' common law deterrence purpose. Even though improving predictability is consistent with optimal deterrence, and possibly even complete deterrence, the Court otherwise rejects the common element of both theories-increasing damages based on the possibilities of under-detection or under-enforcement. Justice Holmes's relatively tame bad man does not consider the possibilities, and the Court similarly assumes them away. Separately, the Court also rejects optimal deterrence by affirming the imposition of punitive damages in Exxon Shipping Co.

\section{a. The Relevance of Predictability}

One initial reaction to Exxon Shipping Co. was that its focus on predictability crippled the deterrence purpose of punitive damages. "It is the unpredictability of punitive damages that in some instances, at least, gives them their greatest deterrent effect." 239 This position is debatable, however. Many believe that predictability actually increases the deterrent effect. $^{240}$

238 See supra Part II.C.2.

239 Alexandra B. Klass, Punitive Damages After Exxon Shipping Company v. Baker: The Quest for Predictability and the Role of Juries, 7 U. ST. Thомas L.J. I82, 198 (2009); see also Brian Timothy Beasley, North Carolina's New Punitive Damages Statute: Who's Being Punished, Anyway?, 74 N.C. L. REv. 2174,2 I 98 ( 1996 ) ("If awards become predictable, large wealthy corporations may include them as a cost of doing business and thus will not be deterred from marketing unsafe products."); Rendleman, supra note 86 , at I9 ("[T]he possibility of a large but randomized sanction may also deter a potential miscreant."); Amelia J. Toy, Statutory Punitive Damage Caps and the Profit Motive: An Economic Perspective, 40 EMORY L.J. 303, 324-26 (I99I) (arguing that "unpredictability is the essence of deterrence"); Paul J. Zwier, Due Process and Punitive Damages, 1991 UTAh. L. Rev. 407, 422-23 ("IT]he only deterrence for the bad-faith tactic is the uncertainty of punitive damages. Certainty in punitive damages would not deter bad-faith conduct."). Similarly, enabling tortfeasors to plan for punitive damages as a cost of doing business negates any punishment effect-discouraging the conduct by imposing higher costs neutralizes the message that the defendant should not commit the conduct because of its immorality.

240 See, e.g., Pac. Mut. Life Ins. Co. v. Haslip, 499 U.S. I, 59 (I991) (O'Connor, J., dissenting) (rejecting the argument that only "wildly unpredictable" awards could best achieve deterrence). In the criminal context, the Court has noted the deterrent effect of a criminal punishment depends both on the amount and the certainty of the penalty. Harmelin v. Michigan, 50I U.S. 957, 989 (1991); Furman v. Georgia, 408 U.S. 238, 354 n.124 (1972) (Marshall, J., concurring) ("For capital punishment to deter anybody it must be a certain result of a criminal act, ... and it is not."); see also E. Donald Elliott, Why Punitive Damages Don't Deter Corporate Misconduct Effectively, 40 AlA. L. Rev. I053, 1062 (I989) ("In the criminal law, it is generally recognized that three factors increase the deterrent effect of sanctions: swiftness, 
Predictability, moreover, is actually required for optimal deterrence. "Uncertainty is inconsistent with optimal deterrence because it imposes additional costs, beyond the expected penalty itself, and could make it impossible for potential tortfeasors or their insurers to predict liability in order to decide whether proceeding despite the risk of liability would be profitable." ${ }^{241}$ Uncertainty results in overdeterrence, which will cause would-be defendants to undertake excessive precautions and pass those costs on to consumers, or perhaps deter would-be defendants from even undertaking the activity. ${ }^{242}$ To avoid overdeterrence, optimal deterrence injects more certainty and predictability into punitive damages. ${ }^{243}$

Also, increasing predictability is not necessarily inconsistent with complete deterrence. Unlike optimal deterrence, complete deterrence is not concerned with the possibility of overdeterrence-thus, there is no need to eliminate uncertainty and unpredictability. ${ }^{244}$ At the same time, making the damages more predictable should not interfere with achieving complete deterrence. And predictability may also increase naturally if the jury were to use the gain-elimination formula. ${ }^{245}$ Thus, the Court's focus

certainty, and magnitude."). And in the "fierce debates" over the federal criminal sentencing guidelines, which increase predictability, "no serious consideration appears to have been given to the possibility that increasing certainty might undercut deterrence." Tom Baker et al., The Virtues of Uncertainty in Law: An Experimental Approach, 89 Iowa L. REv. 443, 451-52 (2004).

The Court has also discussed the effect of certainty on deterrence in other contexts. For example, the Court has mentioned that the unpredictable enforcement of Federal Rule of Civil Procedural Rule I I sanctions for frivolous filings has hurt the sanctions' deterrent effect. Cooter \& Gell v. Hartmarx Corp., 496 U.S. 384, 392-93 (1990). Also, the "primary rationale for the exclusionary rule is to deter official misconduct." Jarvis v. United States, 435 U.S. 934,936 (1978). The Court has often commented on the need to provide specific guidance to police officers to achieve that deterrence. See Dunaway v. New York, 442 U.S. 200, 21 3-1 4 ( 1979). For general arguments that predictability is consistent with deterrence, see Elliott, supra note 239, at 1058 ("[O]nly information about the liability consequences of specific practices or modes of engaging in the activity is likely to enhance specific predictability and thereby shape the way that the activity is conducted."); Schwartz, supra note 65 , at 141 ("From a deterrence standpoint, it confounds understanding to permit such vast uncertainty as to the level of the expected penalty.").

241 Scheiner, supra note 26 , at 178.

242 See supra notes $42-44$ and accompanying text.

243 Whether the cost-internalization measurement of optimal deterrence actually achieves predictability is debatable given that it assumes pre-tort knowledge of the amount of compensatory damages. The amount of compensatory damages, however, is likely not knowable to the defendant before commission of the tort because it depends on "the specific plaintiff, her circumstances, and her injury." Lens, supra note 73, at 39. In Exxon Shipping Co., the Court similarly (and mistakenly) assumed that the amount of compensatory damages is knowable in concluding that its ratio system would provide predictability. Id. at 38-39.

244 Scheiner, supra note 26 , at 178 ("If the goal is total deterrence, then overdeterrence is impossible....").

245 See Lens, supra note 73, at 66-70 (advocating a gain-based measurement of punitive damages and arguing it would achieve predictability). The gain-elimination formula, however, sets only a minimum, leaving room for higher, unpredictable awards. 
on predictability is actually consistent with optimal deterrence and not inconsistent with complete deterrence.

\section{b. Under-Detection and Under-Enforcement? No problem.}

Both optimal and complete deterrence theories conclude that punitive damages cannot achieve deterrence unless the damages are increased to reflect the possibility of escaping liability, whether because of underdetection or under-enforcement. ${ }^{246}$ If the defendant has a $50 \%$ chance of escaping liability, his punitive damage award, whether based on the harm caused to the plaintiff or the defendant's gain depending on the theory, should be doubled.

Just like it has in its constitutional cases, the Court appeared to agree in Exxon Shipping $\mathrm{Co}^{247}$ Once again, the Court recycled its higher ratio language: "[H]eavier punitive awards have been thought to be justifiable when wrongdoing is hard to detect (increasing chances of getting away with it) or when the value of injury and the corresponding compensatory award are small (providing low incentives to sue)." 248

The Court's description of its ideal system, however, assumes away concerns related to under-detection and under-enforcement. The Court wants punitive damages to be "reasonably predictable" so that Justice Holmes's bad man, and the next bad men, understand "the stakes ... in choosing one course of action or another." 249 This described thought process assumes that the bad man will pay damages if he commits the tortious conduct, including punitive damages. This thought process does not consider the likelihood of escaping liability or the likelihood of not having to pay punitive damages. The "stakes" for the bad man include punitive damages, which is why the Court focuses on making the amount of these damages knowable pre-tort.

The Court's analysis tracks Justice Holmes's. His bad man also assumed that he would have to pay damages if he committed a tort. The bad man's failure to account for the possibility that he may not have to pay damages is why some have labeled him "tame." ${ }^{250}$ The Court takes the assumption a step further though-also assuming that the bad man will pay punitive damages despite the multiple factors that must fall into place for the

246 See supra notes $32-48$ and accompanying text.

247 Sharkey, supra note 60 , at 2 I ("By rejecting the under-detection rationale in the case at hand, the Court both affirmed the relevance of the economic justification and implicitly sided with the loss-internalization model over that of the gain-elimination model ....").

248 Exxon Shipping Co. v. Baker, 554 U.S. 471, 494 (2008) (citations omitted). Of course, the Court has never actually applied this notion in its prior mentions. See supra notes 77-79 and accompanying text.

249 Exxon Shipping Co., 554 U.S. at 502.

250 Luban, supra note 151 , at 1571. 
damages to be imposed. These factors include the plaintiff requesting punitive damages, the judge allowing the plaintiff to submit that request to the jury, the plaintiff convincing the jury to impose the damages, ${ }^{251}$ the court not reducing the damages, etc.

Any assumption that the bad man will pay damages if he commits tortious conduct rejects the shared premise of optimal and complete deterrence. Again, both theories conclude that deterrence cannot be achieved unless damages are increased based on the chances of escaping liability. The Court, however, like Justice Holmes's bad man, does not acknowledge the relevance of the chances of escaping liability. The Court's current conception of punitive damages' deterrence purpose thus includes neither optimal nor complete deterrence.

\section{c. Imposing Punitive Damages Despite Guaranteed Liability}

In Exxon Shipping Co., the Court specifically concluded that the defendant had no chance of escaping liability, ${ }^{252}$ but the Court still affirmed the imposition of punitive damages. Granted, the Court reduced the award consistent with its chosen 1:1 punitive to compensatory damage ratio, but it still imposed an award despite guaranteed liability.

25I See DobBs, supra note 20, $\$ 3$. I I ( 1 ), at 3 I 4 ("If the facts justify submitting the punitive damages issue to the jury, the jury is free to make the award, to limit it, or to deny it altogether, even if the facts show egregious misconduct by the defendant."); see, e.g., Scheuerman \& Franze, supra note 93, at I I67-69 n. I34-39 (describing the punitive damage jury instructions from Alabama, Missouri, Ohio, Utah, Vermont, and Virginia, all of which instruct the jury that it has the discretion whether to award punitive damages at all).

The Exxon Shipping Co. Court acknowledged the jury's discretion over imposition; this discretion is actually the basis of the unpredictability in the anecdotal evidence that the Court mentions-the comparison between the $\$ 4$ million punitive damage award in $B M W$ and the refusal to award any punitive damages in a case with similar facts. The Court does not connect how, as long as the jury retains this discretion, punitive damages will remain unpredictable to some extent. Pac. Mut. Life Ins. Co. v. Haslip, 499 U.S. I, 43 (I991) (O'Connor, J., dissenting). Even if a ratio-type system could help fix predictability issues related to the amount of the award, two distinct possibilities will remain: either the jury will award that amount or the jury will not award any punitive damages.

Polinsky and Shavell do not specifically identify the jury's discretion in imposing punitive damages as a possible basis for under-detection or under-enforcement; nor should they, since their "escaping liability" analysis assumes liability for compensatory damages. After the defendant is sued and the jury is considering whether to award punitive damages, however, both optimal and complete theories assume that the jury will impose punitive damages. See Polinsky \& Shavell, supra note 30, app. at 957-59 (listing model jury instructions, which do not include the traditional "you may award punitive damages" language). If the jury retained discretion over whether to impose, the defendant would always have a chance of not paying any damages, preventing the achievement of either optimal or complete deterrence because the defendant would not always end up paying the total harm caused or be stripped of the total gain, respectively.

252 See Exxon Shipping Co., 554 U.S. at 5 II. 
This result is inconsistent with optimal deterrence. Under optimal deterrence, if the tortfeasor "has virtually no chance of escaping liability," 253 meaning there is no chance of under-detection or under-enforcement, punitive damages would be inappropriate. ${ }^{254}$ If liability is guaranteed, the defendant will pay for all of the harm it causes and no additional damages are needed to achieve the proper level of deterrence. Any punitive damages imposed would cause overdeterrence, a socially undesirable result. If the Court wanted to embrace optimal deterrence as a part of punitive damages' common law deterrence purpose, it should not have imposed any punitive damages given the chances of overdeterrence. ${ }^{255}$

The Court's willingness to impose punitive damages despite the guaranteed liability is, however, consistent with complete deterrence, which allows damages despite guaranteed liability to ensure that the tortfeasor is completely stripped of any gain. ${ }^{256}$ Still, the Court's analysis of the deterrence purpose in Exxon Shipping Co. does not otherwise track complete deterrence, as the Court does not begin with or focus on the

253 Polinsky \& Shavell, supra note 30, at $89 \mathrm{I}$.

254 See supra note $4 \mathrm{I}$ and accompanying text. The proponents of the cost-internalization theory even point to the Exxon Valdez oil spill as an example of this situation. See Polinsky $\&$ Shavell, supra note 30 , at $891 \& \mathrm{n} .5^{6}$. This is not surprising because Professors Polinsky and Shavell served as consultants for Exxon Corporation within its numerous appeals of the punitive damage award. Id. at 870 n.a I.

Professor Calandrillo also advocates a deterrence-based cost-internalization method of calculating punitive damages, but he believes that punitive damages were appropriate because Exxon Shipping Co. "ended up escaping liability for many of the harms it caused due to the quirks of the governing maritime law." See Calandrillo, supra note 98, at 8I 7. The phrase "escapes liability," however, assumes that liability is possible; if the governing law does not recognize any possibility of liability, there is no liability to escape. Professor Calandrillo's criticism is more aptly directed at maritime law on compensatory damages. See Polinsky \& Shavell, supra note 30, at 939 ("[R]emedies for missing components of harm would be best pursued through revision of the rules used to calculate compensatory damages.").

255 The Court also could have awarded something less than the I: I ratio. Even within its analysis, the Court found the median ratio to be under I:I, but then chose a I:I ratio for this case. Exxon Shipping Co., 554 U.S. at 515.

256 Professor Hylton's analysis of the proper punitive damage award in Exxon Shipping Co. has multiple parts. If the activity at issue is economically desirable, the cost-internalization approach should apply. See Hylton, supra note 45 , at $452-53$. But if the activity is considered "incompetent[ly] ... pilot[ing] a supertanker":

\footnotetext{
To find the appropriate penalty under the less favorable view of events offered here, one must determine Exxon's gain from employing an incompetent captain. This gain is probably small, as it is the difference between the cost of employing Joseph Hazelwood and that of employing a competent ship captain. Given that the likelihood of detection, identification, and suit was $100 \%$, there would be no need to inflate this gain estimate to correct for the chance the defendant would avoid punishment. This estimation procedure suggests that the minimum gaineliminating penalty is far less than the $\$ 5$ billion punitive award. On the other hand, if we are sure that the Exxon's activity is one that merits a gain-eliminating penalty, then there is no reason to believe, on deterrence grounds, that the $\$ 5$ billion punitive award against Exxon is excessive.
} 
defendant's expected gain from its conduct. ${ }^{257}$ Thus, just like with optimal deterrence, the Court's described deterrence purpose does not include complete deterrence.

2. Some Generic Notion of Deterrence Survives.-Despite the Court's rejection of optimal and complete deterrence as inconsistent with punitive damages' common law deterrence purpose, Exxon Shipping Co. shows that the Court believes that deterrence has a place within punitive damages. This is clear from the Court's focus on the decision whether to commit the tortious conduct. Specifically, the Court wants Justice Holmes's bad man to know the likely amount of punitive damages when he is evaluating the "the stakes ... in choosing one course of action or another." ${ }^{258}$ This reflects a deterrence focus-presumably, the hope is that those stakes will dissuade the potential tortfeasor from committing tortious conduct in the first place. ${ }^{259}$

If this presumption is what the Court had in mind, however, the Court acted in opposition to how some scholars interpret Justice Holmes's purpose for introducing the bad man's perspective. The interpretation is that legislatures should consider the bad man's perspective to ensure that remedies will actually force the bad man to change his behavior. ${ }^{260}$ Punitive damages will (supposedly) force that behavior change because of the bad man's inability to calculate the damages. ${ }^{261}$ In Exxon Shipping Co., however, the Court enables the bad man to calculate the damages-facilitating the bad man's activities and "allow[ing] him to become evil, rather than forcing him to behave as though he were good." 262

Regardless of whether predictability facilitates the bad man, the Court presents some deterrence purpose by focusing on the decision-making process. And the Court's idea of deterrence is broader than specific

257 See Exxon Shipping Co., 554 U.S. at 473 (focusing on the idea that a penalty should be reasonably predictable with no reference to expected gain).

258 Id. at 502.

259 Deterrence is thus preemptive. In contrast, punishment occurs post-conduct; it is proper if what the defendant did is morally reprehensible and deserving of punitive damages. It is reactionary. The Court's focus is preemptive deterrence, not reactionary punishment.

260 See, e.g., Jimenez, supra note I35, at 2 I 26 (arguing that Justice Holmes's purpose was for lawmakers to consider the bad man's perspective so they could change the law to affect his decision-making for the benefit of the public). Changing the laws, if done effectively, should deter the potential tortfeasor. Id. at 2115-16 ("Holmes's insistence on the separation of law and morality exists to help us understand the bad man view of law, which in turn helps us understand why the bad man behaves as he does, which in turn helps us deter the bad man, which in turn helps us protect the good man.") (emphasis added) (footnote omitted).

26I See Grey, supra note 134, at 36, 54 (explaining that to reach Justice Holmes's bad man, a legislature should look "to criminal penalties, punitive damages, or injunction, not just compensatory damages").

262 Jimenez, supra note 135, at 2 126. Professor Jimenez argues that the Supreme Court misunderstood Justice Holmes's purpose as empowering the bad man. Id. 
deterrence of the potential tortfeasor. The Court also wants the "bad man's counterparts" to similarly be able to look ahead and see that they will face a "penalty scheme [that] ... threaten[s] them with a fair probability of suffering in like degree when they wreak like damage." ${ }^{663}$ As soon as the Court mentions the bad man's counterparts, the concept of deterrence expands from specific to general, even though many thought that the Court rejected general deterrence as an unconstitutional aim of punitive damages. ${ }^{264}$

That is as far as the Court goes, however, in describing the common law deterrence purpose of punitive damages. There is no indication if what is desired is a total deterrence attempting to prohibit the conduct under all circumstances or if the conduct is sometimes desirable. There is no indication of how the punitive damages can achieve this "deterrence" when there is no possibility of increasing the damages based on the chances of escaping liability (because the Court believes those chances to be irrelevant). The Court's lack of explanation is even more striking given the decision's common law basis; it leaves the damages with an aimless deterrence purpose.

\section{The Unavoidable Unconstitutionality of Punitive Damages}

The state can constitutionally impose punitive damages to further its legitimate interests in punishment and deterrence. ${ }^{265}$ The state's interests in imposing these damages have always matched the damages' traditional common law punishment and deterrence purposes. ${ }^{266}$ Change those purposes, however, and the constitutionality of punitive damages falls apart. In Exxon Shipping Co., the Court does just that. It describes a punishment

263 Exxon Shipping Co., 554 U.S. at 502.

264 See supra notes $96-98$ and accompanying text (describing the Court's rejection of general deterrence in Philip Morris); Colby, supra note 24, at 463-64 (describing the remaining deterrence "interest in ensuring that the defendant does not victimize her again"); Scheuerman, supra note 30 , at 933 .

One possible explanation is that Philip Morris is a constitutional limitation, which would trump the common law vision of deterrence in Exxon Shipping Co. The better reading of Philip Morris, however, is that it constitutionally limits the punishment purpose of punitive damages. The Court is clearly concerned about damage awards including amounts for harms the defendant had already caused to nonparties-a reactionary punishment focus. Similarly, the Court's due process analysis focuses on past harms. First, the Court was concerned about the defendant's opportunity to defend itself against allegations that it harmed nonparties. Philip Morris USA v. Williams, 549 U.S. 346, 353-54 (2007). Second, the Court was concerned about a "standardless dimension to the punitive damages equation. How many such victims are there? How seriously were they injured? Under what circumstances did injury occur?" Id. at 354. Philip Morris limits punitive damages' punishment purpose by limiting the scope of what conduct is punishable through an award.

265 BMW of N. Am., Inc. v. Gore, 5 I 7 U.S. 559, 568 (1996).

266 See supra text accompanying notes $54-55$. 
with no basis and a generic "deterrence" unconcerned with the chances of escaping liability. ${ }^{267}$ These concepts are insufficient to constitutionally justify the imposition of punitive damages.

The imposition of punitive damages as conceived in Exxon Shipping Co. cannot further a state's traditional morality-based punishment interest. The divorce from morality also threatens the damages' status as a "punishment" given its failure to express moral condemnation. But even if they were still a punishment, the wrongdoer, aka Justice Holmes's bad man, does not appreciate that moral condemnation or any stigma. Under the Court's description, the damages are hardly a punishment.

With respect to deterrence, the Court has already emasculated the purpose in describing its inability to constitutionally justify an award. ${ }^{268}$ Within its common law authority in Exxon, the Court describes a concept of "deterrence" that does not match how the concept is more commonly understood. The Court also gave no explanation regarding how the damages might achieve deterrence and hurt the damages' ability to achieve any notion of deterrence by failing to acknowledge the effects of underdetection and under-enforcement. Without some consideration of the chances of escaping liability, punitive damages have less ability to achieve whatever type of deterrence the state might seek.

Imagine that Exxon Shipping Company was able to challenge, constitutionally, its reduced punitive damage award. The common law purposes, as conceived by the Court in Exxon Shipping Co., preclude the award's constitutionality. Why was punishment appropriate? It cannot be because of the defendant's immoral conduct. Punishment regardless of immorality does not further a state's interest in punishing immoral conduct. But more importantly, without morality, do the damages even constitute a punishment? Was Exxon Shipping Company even punished when it was forced to pay the punitive damages, or was it just subjected to another fine? These unanswered questions make it impossible to conclude that the damages sufficiently further a legitimate state punishment interest, and thus the damages are unconstitutional.

Similarly, the punitive damage award cannot be justified by the vague notion of generically discouraging tortious conduct-not even an award equal to the compensatory award. How many other potential tortfeasors would otherwise choose to incompetently pilot supertankers carrying millions of gallons of oil in the absence of the punitive damage award? Probably none. And problematically, some companies may choose to not transport oil at all because of the potential of punitive damages. It is far from clear that imposing punitive damages would accomplish even some vague idea of deterrence. The Court's description of punitive damages'

267 See supra Parts IV.A.2, IV.B.2.

268 See supra Part II.C.2. 
punishment and deterrence purposes demonstrates that the damages cannot further legitimate state interests in punishment or deterrence, making the damages unconstitutional.

The Court has always assumed that the state's interests and the damages' common law purposes are identical, so perhaps the Court also meant to redefine the state interests served by imposing punitive damages to mirror the described common law purposes. ${ }^{269}$ If this is true, the imposition of punitive damages as described by the Court in Exxon Shipping Co. would further the state interests. However, those state interests would no longer be legitimate - as they must be for the imposition of damages to be constitutional. ${ }^{270}$

A state interest in "punishment" as described by the Court is not legitimate. The Court rejected morality-based punishment, ${ }^{271}$ leaving -based punishment-but the Court did not fill in the blank. A state interest in ____based punishment cannot be legitimate; there is no basis to explain why, when, or how much punishment is appropriate.

Similarly, the idea of "deterrence" that the Court describes is not a legitimate state interest. Even before Exxon Shipping Co., the Court's holdings left the deterrence purpose looking impotent, constitutionally speaking. When given the chance to directly address the substance of this purpose in Exxon Shipping Co., the Court described a generic and hollow concept of deterrence. 272 The Court rejected defined goals like optimal or complete deterrence. ${ }^{273} \mathrm{It}$ is difficult for a state interest in deterrence to be legitimate when the concept remains undefined.

Aside from issues related to the state interests, punitive damages with common law purposes as conceived by the Court in Exxon Shipping Co. are separately unconstitutional because of their arbitrary imposition. The

269 This assumption is rational given how the Court has always assumed that the damages' purposes match the state interests in imposing the damages. See Part II.C.

$270 \mathrm{See}$ Part II.C. A tortfeasor has a substantive due process constitutional right protecting her from the imposition of a punitive damage award unsupported by sufficient state interests. $B M W, 517$ U.S. at 568 ("Only when an award can fairly be categorized as 'grossly excessive' in relation to these interests does it enter the zone of arbitrariness that violates the Due Process Clause of the Fourteenth Amendment."). The Court does not usually explain the constitutional challenge based on the tortfeasor's right, instead focusing on the state's inability to impose an award. A consequence of the Court's focus on the state's inability is that we do not know if the tortfeasor's constitutional right is fundamental. If it is a fundamental right, state action infringing on it is constitutional only if justified by a compelling state interest and the state action is narrowly tailored to achieve that state interest. See Roe v. Wade, 410 U.S. 113, I 55 (1973). If it is not a fundamental right, state action infringing on it is constitutional if justified by a legitimate state interest and the state action is reasonably related to achieving that state interest. Alexander v. Whitman, I 4 F.3d 1392, 1403 (3d Cir. 1997). Under either review though, if the state interest is illegitimate, the state action would be unconstitutional.

27 I See supra Part IV.A.I.

272 See supra Part IV.B.2.

273 See supra Part IV.B.1. 
Constitution prohibits "the imposition of grossly excessive or arbitrary punishments on a tortfeasor." 274 'The Court removed the traditional morality basis for imposition and failed to replace it. After Exxon Shipping Co., there is no basis for imposition, much less a principled one. And without a basis, the imposition of punitive damages is arbitrary and unconstitutional.

Unconstitutionality aside, punitive damages' common law purposes justify the damages' existence. 'The highest Court in the nation, however, thinks that punitive damages "punish" for an unclear reason and generically "deter" even when not necessary. These descriptions leave little reason to retain the damages from a policy perspective. Again, the traditional morality-based punishment purpose and the possibility of deterrence are the very reasons that courts created the damages. Without that purpose and possibility, the reasons for the damages' existence are gone-which should further motivate both legislative and court reform of punitive damages. ${ }^{275}$

\section{Conclusion}

Justice Holmes's bad man sees the law as its consequences. Committing a tort such as fraudulent misrepresentation, for example, simply means an obligation to pay a compensatory sum. The immorality of lying does not sway the bad man; he sees only the price tag. This man, ignorant of morality, is who the Court chose to invoke in its special opportunity to describe how punitive damages should work-even though punitive damages have been inextricably linked to morality for centuries. The Court described a system in which even Justice Holmes's bad man should be able to fully appreciate the total price tag of his tortious conduct, composed of both compensatory and punitive damages.

What does this mean for punitive damages jurisprudence? It alters it dramatically. The Court, acting properly within its common law authority, redefined punitive damages' common law punishment and deterrence purposes. This is important because the changed purposes may hurt the continued justifiability of punitive damages from a policy perspective. But the more important effect of the changed purposes is constitutional. Punitive damages' common law purposes justify them constitutionally;

274 State Farm Mut. Auro. Ins. Co. v. Campbell, 538 U.S. 408, 4 I6 (2003).

275 Most reform of punitive damages has come from legislatures. See sources cited supra note 22 I. In Exxon Shipping Co. v. Baker, 554 U.S. 47 I (2008), however, the Court blamed courts for the problematic evolution of punitive damages and urged courts to fix that problem: "[I]n the absence of legislation, ... it is hard to see how the judiciary can wash its hands of a problem it created ...." Id. at 507. Judicial reform of common law doctrine would not be unprecedented. For instance, numerous state supreme courts rejected the traditional contributory negligence bar and adopted a form of comparative fault. See McIntyre v. Balentine, 833 S.W.2d 52, 55-56 (Tenn. 1992) (describing that eleven states judicially adopted a form of comparative fault and that legislative inaction has never prevented judicial abolition of obsolete common law doctrines, especially those created by the judiciary). 
altering the purposes can undercut their constitutionality. Surprisingly, the Supreme Court case that does the most damage to the constitutionality of punitive damages was not a constitutional challenge-the challenge was based on boat law.

After Exxon Shipping Co., the punitive damages' punishment purpose is unconnected to morality. The damages are not imposed based on the immorality of conduct, the damages do not express moral condemnation, and that moral condemnation is incapable of creating any punishing stigma. Without the morality basis, it is not even clear that the damages constitute a "punishment." The Court removes the basis of the punishment purpose but does not replace it, so we are no longer sure why or how punitive damages "punish."

The common law basis of Exxon Shipping Co. gave the Court an opportunity to give the deterrence purpose independent substance, possibly by adopting optimal or complete deterrence. Instead, the Court rejected both theories by assuming away the relevance of under-detection and under-enforcement; Justice Holmes's bad man will pay both compensatory damages and punitive damages. Plus, the Court imposed punitive damages despite guaranteed liability and the overdeterrence that will likely result. The Court insists that the deterrence purpose is alive and well, but it is a meaningless and possibly unnecessary "deterrence."

These described purposes of punitive damages make the damages a bit pointless. More importantly, though, they make the damages unconstitutional. Punitive damages no longer further legitimate state interests in punishment and deterrence. Their imposition is arbitrary given that there is no standard. If state interests now mirror the common law purposes the Court described in Exxon Shipping Co., those rewritten state interests are not legitimate and cannot justify, constitutionally, the imposition of punitive damages.

Exxon Shipping Co. seems like a harmless case. It has been largely ignored by academics because of its common law basis. Its common law basis, however, was how the Court was able to so dramatically affect the constitutionality of punitive damages. Punitive damages' common law punishment and deterrence purposes ensure that the damages further legitimate state interests, making punitive damages constitutional. By depleting the common law purposes, the Court undercut that constitutionality. Exxon Shipping Co. is far from harmless; it should be the last nail in the coffin for punitive damages. 
